\title{
Progress in the inhibition of metal corrosion and the prospects of its use in the oil and gas industry ${ }^{1}$
}

\author{
Yu.I. Kuznetsov,* A.A. Chirkunov and A.M. Semiletov \\ A.N. Frumkin Institute of Physical Chemistry and Electrochemistry, Russian Academy of \\ Sciences, Leninsky pr. 31, 119071 Moscow, Russian Federation \\ *E-mail:yukuzn@gmail.com
}

\begin{abstract}
A brief review of the main scientific areas of research and development of efficient corrosion inhibitors of metals (CIs) and their application methods is given. Temporary protection against atmospheric corrosion of steel pipes and equipment for storage (at least one year) or during transportation is often achieved by passivation using aqueous solutions of non-toxic CIs. They efficiently protect not only steel, but also copper or aluminum alloys; therefore, they successfully replace environmentally hazardous passivating solutions, not only nitrite but also chromate ones. Such solutions are often based on salts of higher carboxylic acids, for example, oleic acid or oleoylsarcosine. Temporary protection includes the use of vapor phase CIs, which, in addition to traditional volatile CIs, include the recently proposed so-called chamber CIs. A relatively new and rapidly developing method of temporary protection of metals is the superhydrophobization of their surface, which provides water contact angles $\theta$ above $150^{\circ}$. CIs are used in solutions of strong acids that are injected into the reservoir to increase oil production and in $\mathrm{H}_{2} \mathrm{~S}$-containing media in the fight against corrosion and hydrogenation. Examples of CI applications in paint systems, and more precisely in the primer layer, where they are introduced being immobilized in micro or macro containers to prevent the adverse effect of a CI on the coating while maintaining a high efficiency of metal corrosion protection, are considered. To prevent the destruction of high-pressure gas pipelines, it is important to slow down not only steel corrosion, but also its stress corrosion cracking (SCC). The properties of CIs that are necessary for their use in polymer coatings to reduce the accident incidence rate due to SCC on gas pipelines are discussed.
\end{abstract}

Keywords: corrosion, corrosion inhibitors, vapor-phase protection, volatile inhibitors, chamber inhibitors, stress corrosion cracking, passivation of metals.

Received: August 10, 2019. Published: October 18, 2019

doi: $\underline{10.17675 / 2305-6894-2019-8-4-5}$

\footnotetext{
${ }^{1}$ This article is based on a report read by one of the authors at the International Conference "Corrosion in the Oil and Gas Industry", which was held in St. Petersburg on May 22-24, 2019. The materials used in the article were partially obtained under the Fundamental Scientific Research Program of the State Academies of Sciences for 2013-2020: "Development of the fundamental scientific foundations of the protective effect of metal corrosion inhibitors in gas and condensed media, nanocomposites, paints and conversion coatings" (State registration number AAAA-A18-118121090043-0).
} 


\section{Introduction}

Corrosion inhibitors (CIs) of metals are usually understood as such chemical compounds or their formulations, the presence of which in small amounts in a corrosive environment or on the surface of a metal protects the latter from corrosion without significantly changing the concentration of the corrosive components in the environment [1-3]. The latter circumstance does not allow oxygen or hydrogen sulfide scavengers to be attributed to CIs, so which form a separate group of anti-corrosion protection agents.

The mechanism of CI action can be quite complex. However, if you don't want to dig deeper into the details that could be quite diverse, then its essence is fully explained by two main phenomena: CI adsorption on the surface of the metal to be protected and/or formation of thin surface layers of hardly soluble compounds of a CI with metal cations. Here, it is necessary to distinguish CIs from rust converters that form thicker layers that distinguishable by the naked eye, and paint and varnish formulations, although they often contain CIs or anti-corrosive pigments that as a rule differ from CIs only in lower solubility.

It is known that about $8 \%$ of the world production of metals is used in oil production, transportation and processing [4]. According to [5], as early as in 1947 a full set of patented organic CIs became available in the USA for use in oil and gas wells. According to J. Bregman [6], it was the appearance of high-molecular organic CI that revolutionized the oil industry, since it extended the operational life of wells by preventing the degradation of their equipment.

Thus, the use of CIs in the oil and gas industry has long been known in many cases, but one still cannot state that they have exhausted their capabilities. The main areas of their application are as follows:

- acid solutions containing CIs are often injected into the formation in order to increase efficiency of oil and gas extraction [7]. The CIs play an important role in the protection of oil and water pipelines. In many cases, the protection of gas collection and purification systems also requires the use of $\mathrm{CI}$, especially in the presence of corrosive gases such as $\mathrm{H}_{2} \mathrm{~S}$ and $\mathrm{CO}_{2}$. CIs play a leading role in the temporary protection of equipment and can protect spare storage pipes, pumps and other ground equipment from corrosion;

- in petrochemical industry, CIs are widely used in primary oil refining facilities, most of which are used for the corrosion protection of condensation and refrigeration equipment. According to [8], hydrocarbon-soluble CIs are used here, which constitute about $30 \%$ of the world production of all CIs. Most of them (about 70\%) are used in oil refining plants. Intensification of refining and increasing its depth aimed at increasing the purification of commodity fuels and accompanied by destructive transformation of raw materials producing corrosive mercaptans, cyanides, rhodanides and phenols, greatly complicates the choice of efficient CIs [9]. 
Another important field of CI application is the protection of steel in gas-air zones of tanks for storage of oil and oil products, including tank lids and parts of its walls that are above the hydrocarbon-air interface. It is not surprising that volatile CIs (VCIs) are used here, but on condition that they do not contaminate oil products, therefore the use of hydrocarbon-soluble VCIs is undesirable. Water-soluble VCIs are most acceptable in this case, but it should be remembered that the high solubility of a VCI in water can lead to its rapid wash-off by condensing moisture and the loss of the protective properties of the film formed by the inhibitor. The specifics of protection of such low-temperature equipment in petrochemical industry are discussed in detail in monographs $[8,10]$;

- protection against corrosion, scaling and biofouling of circulating cooling systems is particularly important for trouble-free operation of the refinery. This problem and its efficient solutions have been repeatedly discussed in the scientific literature for more than half a century $[6,8,10-13]$.

\section{Temporary protection of metal products against atmospheric corrosion}

Protection of metal products or semi-finished products (during storage and transportation) as well as structures from atmospheric corrosion is especially important in the case of lowcarbon and low-alloy steels. At present, it is often achieved by passivation in aqueous solutions of non-toxic and inexpensive CI. Of course, they efficiently protect not only steel, but also copper or aluminum alloys [3,14], so they successfully replace environmentally hazardous passivating solutions, not only nitrite- but also chromate-based ones. These solutions are often based on salts of higher carboxylic acids, for example, oleic acid or oleoylsarcosine.

Figure 1 shows the results of corrosion tests in a heat and moisture chamber (HMC) carried out in accordance with GOST 9.308-85 using samples of low carbon steel (St3) and aluminum alloys (D16 and AMg-31) after passivation in 5\% water solution IFKhAN-39 for $5 \mathrm{~min}$. The passivation of steel in the base passivating solution (39A) creates a thin film on the metals studied $(d \leq 0.2 \mu \mathrm{m})$, which prolongs the incubation period until the appearance of the first corrosion damage, up to 12 days under harsh conditions of HMC with daily moisture condensation on the samples. The $\tau_{\text {cor }}$ can be increased to 20 days by introducing a wax dispersion into this formulation (39B), passivation in which increases the thickness of the protective film $d \sim 10$ fold. However, this does not improve the protection of aluminum alloys ( $\tau_{\text {cor }}=4-5$ days). By choosing synergistic additives for $39 \mathrm{~A}$, i.e. by creating a 39ALG solution, made it possible to increase $\tau_{\text {cor }}$ up to 38 days for St 3 more than fourfold for AD31 and D16 alloys without increasing the film thickness. This allows one to use passivation of this kind for interoperational protection in workshops or in warehouses, but for more stringent storage conditions it is safer to use the $39 \mathrm{U}$ formulation, which combines the increase in protection efficiency with an increase in $d$. 


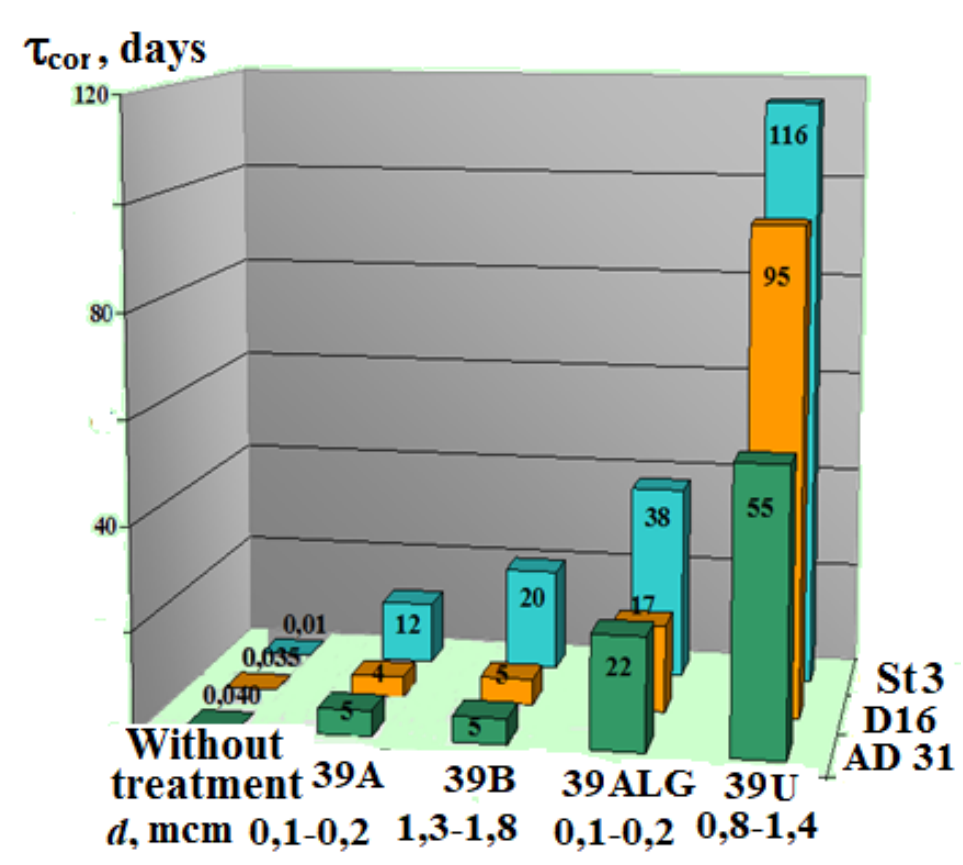

Figure 1. Time before the appearance of the first corrosion damage when testing St 3 and aluminum alloys after passivating their samples in an aqueous $5 \%$ solution of the inhibitor IFHAN-39 in a chamber of heat and moisture [14].

In recent decades, increased attention was paid to the development of ultrathin or nanosized protective films on metals. Conventionally, they can be divided into two types. The first of them are formed from aqueous solutions, therefore the CIs that are part of these films are quite soluble in water, although they are surface active. The second ones are formed by rather hydrophobic CIs and from organic solvents, most often alcohol-based ones. From a practical point of view, the first group of CIs has several advantages over the second one: they are less environmentally and fire hazardous, more economically accessible, and their application is technologically more convenient. However, the low hydrophobicity of these CIs, even if they contain an active "anchor" functional group that provides chemisorption of molecules or anions on a metal to be protected, was the reason why the stability of the films formed by them had been questioned for a long time.

It should be noted that the search for the optimal chemical structure of water-soluble passivating CIs among various organic compounds (salts of carboxylic and phosphonic acids, phosphoric acid esters, azoles, thiazoles and other heterocycles) allowed new efficient CIs to be found find in many cases [11]. These studies were successfully conducted from the mid-1970s till the 1990s with active involvement of the linear free energy relationship (LFER) principle [15]. At the same time, they showed that the prospects for enhancing the efficiency of CIs within the investigated reaction series of organic compounds are limited. The simplest example: an increase in the alkyl length in CIs quickly ceases to give a positive effect due to a decrease in the water solubility of 
higher homologs. In view of this, the question arises: are there any other ways to improve the protective properties of water-soluble CIs?

The discovery of adsorption passivation of iron in neutral aqueous solutions with salts of organic acids in the mid-1970s stimulated studies of the adsorption of organic CIs by in situ methods, mainly ellipsometry [11]. Based on this method, the synergism of adsorption and inhibitory action of two organic acid anions with the same charge with respect to $\mathrm{Fe}$ was explained for the first time. The synergism in the mixture of sodium phenylundecanate $(\mathrm{SPhU}), \mathrm{C}_{6} \mathrm{H}_{5}\left(\mathrm{CH}_{2}\right)_{10} \mathrm{COONa}$, and sodium mefenaminate (SMEF) $\mathrm{NaOOCC}_{6} \mathrm{H}_{4}-(\mathrm{NH})-$ $\mathrm{C}_{6} \mathrm{H}_{3}\left(\mathrm{CH}_{3}\right)_{2}$ is an indicative example. From the results of the adsorption measurement of these CIs (Figure 2, Table 1), it follows that they are adequately described by the Temkin logarithmetic isotherm [16]:

$$
\theta=(1 / f) \ln \left[B_{\max } C\right]
$$

where $\theta$ is the degree of coverage of the metal surface by the adsorbate; $f$ is the surface heterogeneity factor characterizing the change in the adsorption enthalpy with surface coverage; $C$ is the concentration of the adsorbate; $B_{\max }=\exp \left[-\Delta G_{\mathrm{a}}^{0} / R T\right]$ is the adsorption equilibrium constant corresponding to the highest values of the free adsorption energy $\left(-\Delta G_{\mathrm{a}}^{0}\right)$. They are efficiently adsorbed in a wide range of potentials and do not interfere with each other in adsorption, but even enhance it on both oxidized and reduced iron surfaces $[17,18]$.

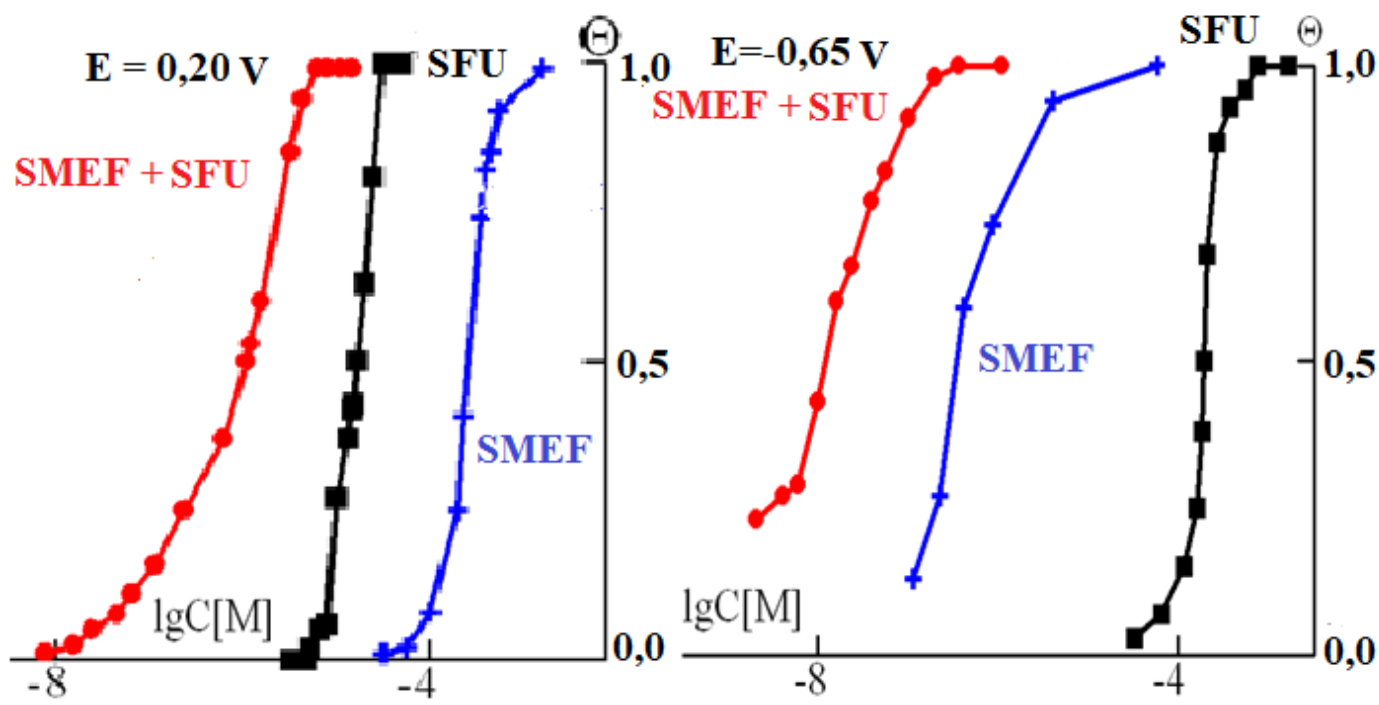

Figure 2. Adsorption isotherms of SMEF, $\mathrm{SPhU}$ and their equimolar mixture on pure iron from aqueous borate buffer solutions with $\mathrm{pH} 7.4$ at electrode potentials $E=0.2 \mathrm{~V}$ and $-0.65 \mathrm{~V}$. In the first case, the electrode was previously passivated at this potential, $i$. $e$. It was covered by oxide film, and in the second - had a reduced surface $[17,18]$. 
Table 1. The values of the free energy of adsorption $\left(-\Delta G_{\mathrm{a}}^{0}\right)$ of carboxylic acid salts and their mixtures on a reduced $(E=-0.65 \mathrm{~V})$ and oxidized $(E=0.20 \mathrm{~V})$ iron electrode, calculated from Eq. (1) based on in situ ellipsometric measurements in borate buffer with $\mathrm{pH} 7.4[18,19]$.

\begin{tabular}{|c|c|c|}
\hline $\begin{array}{c}\text { SMEF } \\
\left(\Delta G_{\mathrm{a}}^{0}\right), \mathrm{kJ} / \mathrm{mol}\end{array}$ & $\begin{array}{c}\text { SPhU } \\
\left(\Delta G_{\mathrm{a}}^{0}\right), \mathrm{kJ} / \mathrm{mol}\end{array}$ & $\begin{array}{l}\text { SMEF+ SPhU } \\
\left(\Delta G_{\mathrm{a}}^{0}\right), \mathrm{kJ} / \mathrm{mol}\end{array}$ \\
\hline \multicolumn{3}{|c|}{$E=-0.65 \mathrm{~V}$} \\
\hline 51.0 & 31.7 & 58.0 \\
\hline \multicolumn{3}{|c|}{$E=0.20 \mathrm{~V}$} \\
\hline 27.3 & 33.1 & 41.7 \\
\hline
\end{tabular}

The highest adsorption energy $\left(-\Delta G_{\mathrm{a}}^{0}\right)$ is characteristic of mixed CIs. At $E=-0.65 \mathrm{~V}$, it is the smallest for the SPhU anions. SMEF has a greater adsorption energy than SPhU, which apparently makes a decisive contribution to the increase in $\left(-\Delta G_{\mathrm{a}}^{0}\right)$ of the mixed CI. On oxidized iron, the difference between the $\left(-\Delta G_{\mathrm{a}}^{0}\right)$ values of the SMEF and SPhU anions is smaller, therefore the mixed $\mathrm{CI}$ has a smaller $\left(-\Delta G_{\mathrm{a}}^{0}\right)$.

Analysis of the adsorption isotherms of these CIs has already shown [17] the important role of the attractive interactions of SMEF with SPhU. By changing the sequence of their adsorption on passive iron, it was demonstrated that adsorption, for example of SMEF, could be enhanced on the electrode surface with preadsorbed SPhU. Interestingly, this occurs more noticeably at large degrees of surface coverage $\theta$ with SPhU anions, despite the fact that the $\left(-\Delta G_{\mathrm{a}}^{0}\right)$ of this CI is higher than that of SMEF. Therefore, $\mathrm{SPhU}$ is not displaced from the surface by SMEF anions in this case.

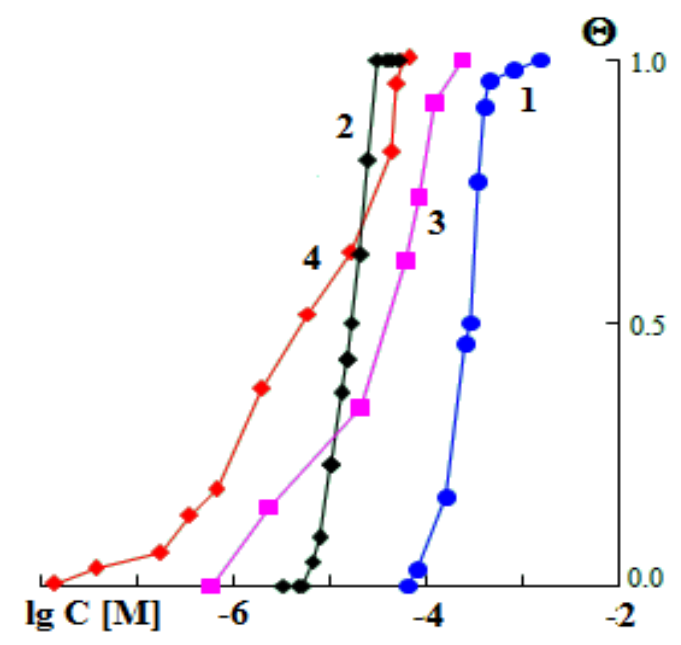

Figure 3. Adsorption isotherms from aqueous borate buffer solution with $\mathrm{pH} 7.4$ on passive iron at $E=0.20 \mathrm{~V} \mathrm{SMEF} \mathrm{(1)} \mathrm{and} \mathrm{SPhU} \mathrm{(2),} \mathrm{and} \mathrm{also} \mathrm{SMEF} \mathrm{(3)} \mathrm{on} \mathrm{the} \mathrm{same} \mathrm{electrode,} \mathrm{but}$ after preliminary adsorption on it of a monolayer SPhU and SPhU (4) sequential formation of SPhU monolayers on this electrode, and then SMEF [19]. 
Further studies presented in Figure 3 showed that the isotherm of SMEF on an electrode that was previously modified by a SPhU monolayer is shifted to the region of its smaller $C_{\text {in }}$ than the isotherm of aromatic amino acid anions on pure oxidized iron $[18,19]$. Calculation of $\left(-\Delta G_{\mathrm{a}}^{0}\right)$ for Eq. (1) for SMEF showed that it increases from 27.3 to $38.4 \mathrm{~kJ} / \mathrm{mol}$. Perhaps even more unexpected is the fact that the preliminary two-stage formation of a $\mathrm{SPhU}+\mathrm{SMEF}$ film on passive iron does not prevent the adsorption of $\mathrm{SPhU}$, the isotherm of which is shifted to the left and its $\left(-\Delta G_{\mathrm{a}}^{0}\right)$ is $39.2 \mathrm{~kJ} / \mathrm{mol}$, i.e., higher than upon the adsorption of SPhU directly on oxidized iron. Corrosion tests confirmed that sequential staged passivation of St3 samples can give them better corrosion resistance in a humid atmosphere with periodic moisture condensation on the samples than the traditional treatment with a solution of a mixture of these CIs.

For a better understanding of the mechanism of the protective action of SPhU and SMEF, IR spectrometry was used [19]. It was found that the maximum of the asymmetric stretching vibration of $\mathrm{COO}^{-}$, which equals $1561 \mathrm{~cm}^{-1}$ for $\mathrm{SPhU}$, is shifted to $1591 \mathrm{~cm}^{-1}$ upon interaction of the $\mathrm{CI}$ with $\mathrm{Fe}$, which according to [20] indicates that a strong bond exists between this anion and iron. In addition, the IR spectrum of iron surface treated with SPhU contains bands of phenylundecanoic acid dimer, the formation of which can strengthen the bonds of organic anions with the metal. They concluded that changes in the IR spectra upon adsorption of SMEF on the surface of an electrode coated with a SPhU monolayer also change the adsorption of anions on passive iron. As a result, aggregates of organic CIs are formed on the surface. They are more firmly bound to it and prevent corrosion.

Further studies have shown that the new approach involving a two-stage treatment of metals with aqueous solutions of non-toxic reagents can be applied not only to two salts of carboxylic acids but also to other CIs. In fact, ellipsometric studies of the adsorption of SPhU and 1,2,3-benzotriazole (BTA) showed that a SPhU monolayer pre-formed on passive St3 significantly enhanced the subsequent adsorption of BTA. This is indicated by the increase in its $\left(-\Delta G_{\mathrm{a}}^{0}\right)$ from 18.3 to $40.5 \mathrm{~kJ} / \mathrm{mol}$ [21]. This is also confirmed by the results of corrosion tests in a humid atmosphere with periodic condensation of moisture on St3 specimens pre-treated with passivating CI solutions $(1 \mathrm{mmol} / 1)$. If the treatment was carried out with a solution of BTA, SPhU or their equimolecular mixture, then the first indications of corrosion on the samples appeared after $\tau_{\text {cor }}=7 ; 51$ and 125 hours, respectively. Upon two-stage passivation, in which the surface was first modified by treatment with a SPhU solution and then with BTA, the value of $\tau_{\text {cor }}$ increased to 225 hours.

Metal complexes, for example zinc phosphonates, can also be used to modify the steel surface $[22,23]$. As one can see from the data presented in Table 2, modification of St3 surface with the zinc complex of 1-hydroxyethane-1,1-diphosphonic acid (HEDPZn) facilitates the adsorption of sodium alkylcarboxylates (SAC). This is easily found from the polarization curves of steel in borate buffer with $\mathrm{pH} 7.4$ containing $1 \mathrm{mM} \mathrm{NaCl}$, from 
which the difference in the pitting formation potentials $\Delta E=E_{\mathrm{pt}}^{\mathrm{in}}-E_{\mathrm{pt}}^{\text {background }}$ is determined, and is confirmed by corrosion tests in the HMC.

Table 2. The results of testing nanoscale coatings formed in aqueous solutions of CIs on St3 low carbon steel for 20 minutes at $60^{\circ} \mathrm{C}$.

\begin{tabular}{ccc}
\hline $\begin{array}{c}\text { The composition of the } \\
\text { passivating solution. The } \\
\text { concentrations } \mathbf{C}_{\text {in }} \text { are expressed } \\
\text { in } \mathbf{m m o l} / \mathbf{l}\end{array}$ & $\begin{array}{c}\boldsymbol{\Delta E}(\mathbf{V}) \text { in borate buffer } \\
\text { containing } \mathbf{~ m M ~ N a C l}\end{array}$ & $\begin{array}{c}\text { The time until the appearance of } \\
\text { the first sign of corrosion (in days) } \\
\text { in HMC tests }\end{array}$ \\
\hline $\begin{array}{c}\text { HEDPZn, } 8 \\
16\end{array}$ & - & - \\
\hline $\begin{array}{c}\text { SAC, } 8 \\
16\end{array}$ & 0.15 & $1.0 \pm 0.1$ \\
\hline HEDPZn, $8-1^{\text {st }}$ layer & 0.25 & $7.0 \pm 0.1$ \\
SAC, $8-2^{\text {nd }}$ layer & 0.41 & $14.0 \pm 0.1$ \\
\hline $\begin{array}{c}\text { HEDPZn, } 16-1 \text { st layer } \\
\text { SAC, } 16-2^{\text {nd }} \text { layer }\end{array}$ & 0.90 & $22.0 \pm 0.3$ \\
\hline HEDPZn, $0.020-1^{\text {st }}$ layer & 0.65 & $30.0 \pm 0.5$ \\
BTA, $4+$ SAC, $4-2^{\text {nd }}$ layer & 0.80 & $50.0 \pm 0.4$ \\
\hline
\end{tabular}

The basis of this increase in the protective effect of SAC lies in the formation of the products of the reaction of electrophilic substitution of zinc by an iron cation in the zinc complex on the steel surface (here L is a ligand, e.g. HEDP):

$$
\mathrm{ZnH}_{n} \mathrm{~L}^{\mathrm{b}-}+2 \mathrm{Fe}^{2+}=\mathrm{Fe}_{2} \mathrm{H}_{\mathrm{n}-2} \mathrm{~L}^{\mathrm{b}-}+2 \mathrm{Zn}^{2+}+2 \mathrm{H}^{+},
$$

and deposition of zinc hydroxide due to the cathodic reaction:

$$
\begin{gathered}
\mathrm{O}_{2}+2 \mathrm{H}_{2} \mathrm{O}+4 \mathrm{e}=4 \mathrm{OH}^{-} \\
4 \mathrm{OH}^{-}+2 \mathrm{Zn}^{2+}=2 \mathrm{Zn}(\mathrm{OH})_{2} \downarrow
\end{gathered}
$$

Modification of steel by the copper complex HEDPCu ( $\tau_{\text {cor }}=50$ days $)$ may be even more efficient, although in this case, to prevent the corrosive effects of copper, it is better to use SAC together with BTA [23]. One of the important advantages of two-stage passivation is the possibility of using CIs that are incompatible in a single passivating solution. In many cases, the protective effect of such coatings is much higher than the passivation in a mixed CI solution where the coating is formed in one stage [24].

In addition, it is possible to modify the surface of the metal to be protected (not only steel but also other metals) with very dilute solutions of a CI that is adsorbed in minimum amounts, i.e., forms only a fraction of a monomolecular layer, $\theta<1.0$, but this is sufficient to significantly improve the adsorption of the second CI. In this regard, large and flat molecules of macrocycles, such as porphyrin and its derivatives, deserve attention. They 
are capable of forming complex compounds with various metals and chemisorbing on their surface [25]. M. Dyer et al. [26] calculated that the plane of the porphyrin macrocycle can be parallel to the $\mathrm{Cu}$ (110) surface and form a chemisorption bond with it due to electron transfer to the almost degenerate vacant low-energy $\pi$-orbital of porphyrin. Later, the adsorption of a protoporphyrin IX derivative was studied in our laboratory, namely, protoporphyrin IX dimegin [2,4-di(1-methoxyethyl)-deuteroporphyrin-IX] disodium salt with the formula shown below, not only on iron or steel [27] but also on copper [28]. It was shown that in all three cases, it is perfectly adsorbed from borate buffer with $\mathrm{pH} 7.4$ on oxidized surfaces of the metals and its adsorption isotherms are adequately described by Eq. (1).

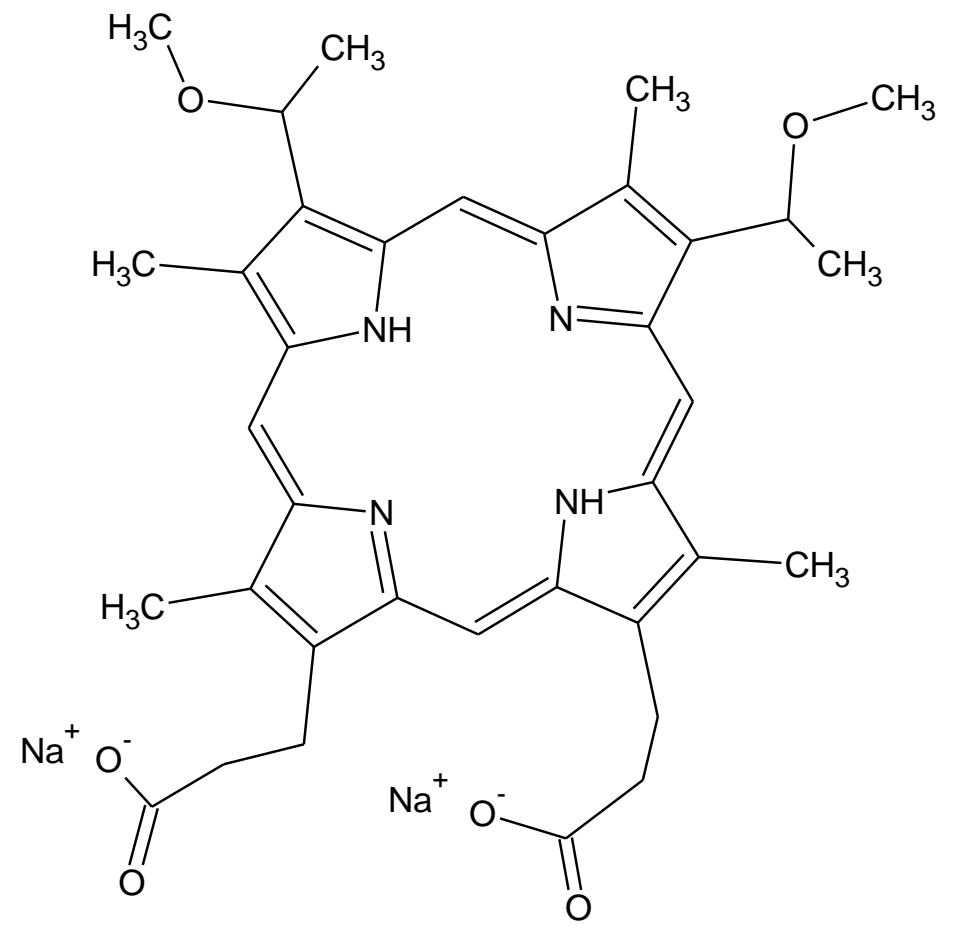

\section{Dimegin [2,4-di(1-methoxyethyl)-deuteroporphyrin-IX] disodium salt}

XPS studies have shown that the bond between dimegin and copper occurs through two donor oxygen atoms of carboxylic groups and its adsorbed particles are oriented obliquely to the surface of copper. The $\left(-\Delta G_{\mathrm{a}}^{0}\right)$ values that amount to $43 ; 51$ and $56 \mathrm{~kJ} / \mathrm{mol}$ for adsorption on $\mathrm{Fe}, \mathrm{St} 3$ and $\mathrm{Cu}$, respectively, indicate that dimegin is chemisorbed on these metals and can be used as a surface modifier to improve the adsorption of other CIs. Indeed, as it is seen in Figure 4, even at a low degree of coverage of copper surface by dimegin, $\theta=0.1-0.3$, it shifts the isotherms of subsequent BTA adsorption to the region of smaller $C_{\mathrm{in}}$, increasing $\left(-\Delta G_{\mathrm{a}}^{0}\right)$ from 58 to $63 \mathrm{~kJ} / \mathrm{mol}$. This makes it possible in principle to use dilute solutions of CIs as passivating solutions without weakening the protection of copper and its alloys from atmospheric corrosion. In fact, after passivation of copper samples in a $1 \mathrm{mmol} / \mathrm{l}$ BTA solution and placing them in the HMC, the first corrosion 
damage on them appeared after 9 days. If they were pretreated in a dimegin solution with $\lg C_{\text {in }}=-8.10$, which corresponds to $\theta=0.47$, and then passivated in the same BTA solution, then $\tau_{\text {cor }}$ reaches 18 days.

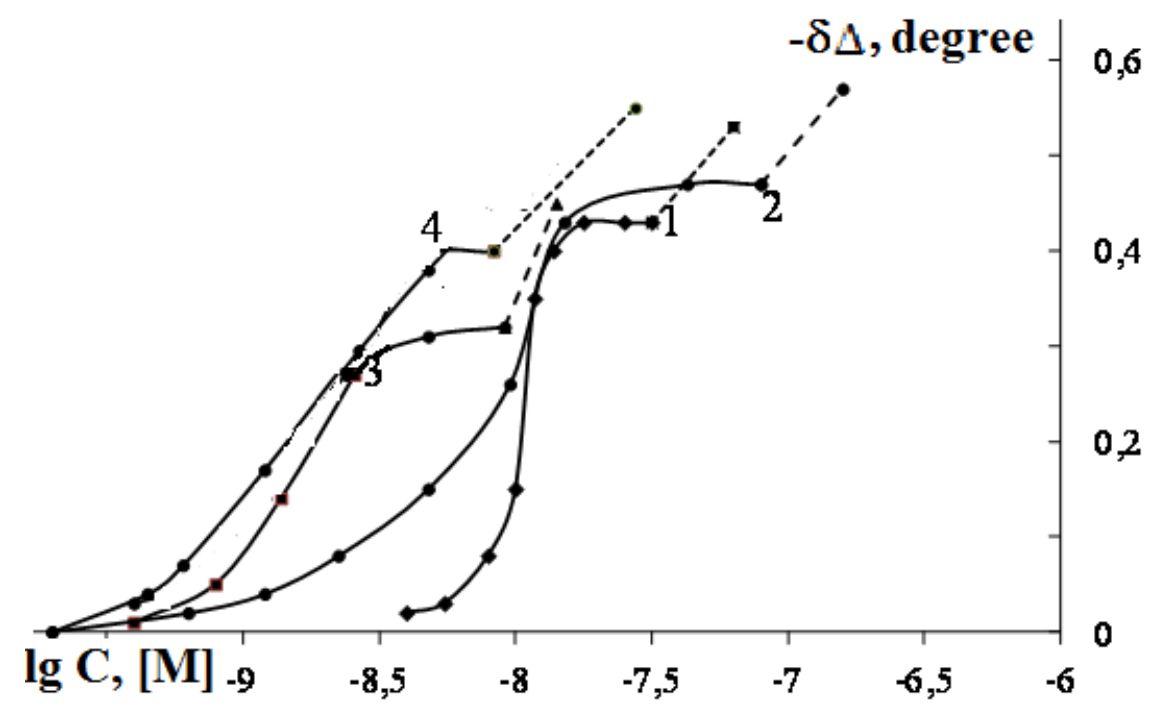

Figure 4. Dependence of the change in the ellipsometric angle $\delta \Delta$ of the logarithm of the BTA concentration on oxidized copper without (1) and with preliminary modification by adsorption of dimegin (2-4). The magnitude of the degree of filling dimeginum copper surface: $2-0.10 ; 3-0.30,4-1.0$.

Yet another way to increase the protective properties of the passivating treatment of metals with aqueous solutions of CIs deserves attention. It involves the use of trialkoxysilanes (TAS) $\mathrm{R}^{\prime}\left(\mathrm{CH}_{2}\right)_{n} \mathrm{Si}(\mathrm{OR})_{3}$, where $\mathrm{R}^{\prime}$ is an organofunctional group and $\mathrm{OR}$ is a hydrolysable alkoxy group, for example $\left(-\mathrm{OCH}_{3}\right)$ or $\left(-\mathrm{OC}_{2} \mathrm{H}_{5}\right)$. These compounds have long been used in paint coatings as adhesives, crosslinking reagents or surface water repellents [29-34]. The peculiarity of the TAS action is that in the presence of water, a hydrolysable alkoxy group can be converted to an active silanol group ( $\mathrm{SiOH})$, which interacts with a hydroxy group on the metal surface to form siloxane $(\mathrm{Si}-\mathrm{O}-\mathrm{Si})$ and metalsiloxane (Me-O-Si) covalent bonds. As shown over the past decades, this makes it possible to use TAS themselves as CIs, including those with a passivating effect [35-44]. A. Frignani et al. [36] proved that incorporation of an alkyl into TAS molecules can increase the protection of AA 7075 aluminum alloy from corrosion by these compounds and the protection efficiency increases with increasing the chain length, $n_{\mathrm{c}}=3<8<18$. They noted that TAS with $n_{\mathrm{c}}=18$ is more efficient in sulphate than in chloride solutions. Its high protective properties, including the protection against atmospheric corrosion, were explained by the greater thickness of the passivating film.

To replace toxic chromates in the protection of aluminum alloys, it seems more promising to use aqueous passivating solutions not of TAS themselves, but of their formulations with other CIs. For example, the passivation of AMg6 alloy in an aqueous 
solution of a mixed $\mathrm{CI}$ (sodium oleoylsarcosinate (SOS) $\mathrm{CH}_{3}\left(\mathrm{CH}_{2}\right)_{7} \mathrm{CH}=\mathrm{CH}\left(\mathrm{CH}_{2}\right)_{7} \mathrm{CON}\left(\mathrm{CH}_{3}\right) \mathrm{CH}_{2} \mathrm{COONa}$ with aminoethyl aminopropyl trimethoxy silane (AEAPTS) $\mathrm{H}_{2} \mathrm{~N}-\mathrm{C}_{2} \mathrm{H}_{4}-\mathrm{NH}-\mathrm{C}_{3} \mathrm{H}_{6}-\mathrm{Si}\left(-\mathrm{O}-\mathrm{CH}_{3}\right)_{3}$ in a $3: 1$ ratio] at $C_{\mathrm{in}}=16 \mathrm{mmol} / \mathrm{l}$ is an efficient method for preventing corrosion not only under HMC conditions but also under the very harsh conditions of a salt fog chamber (SFCh) [40].

Figure 5 shows the test results of AMg6 samples showing that their passivation even in solutions of CIs such as AEAPTS, sodium oleate (SOl), and especially SOS is more efficient for the protection in HMC than chromate passivation. However, although they are superior to it, the advantage is small under more severe SFCh conditions. However, treatment by a solution of the mixed CI is much more efficient, namely, 3.9-fold for HMC and 2.75-fold for SFCh. This formulation also showed high efficiency in passivation of St3 low-carbon steel, preventing the appearance of signs of corrosion in an HMC for $456 \mathrm{~h}$ [39].

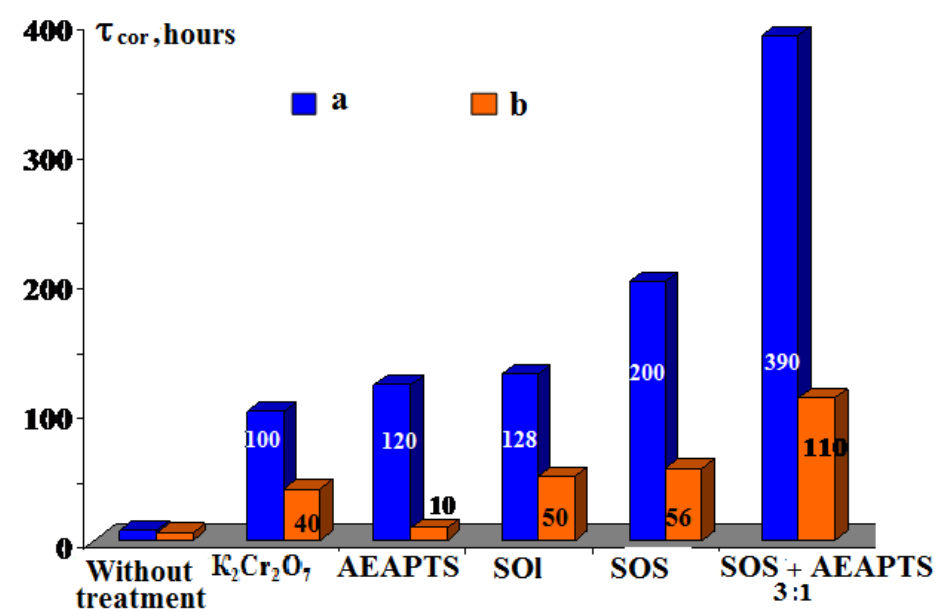

Figure 5. The duration of the induction period before the first signs of corrosion on the samples of AMg6 alloy in the heat and moisture chambers (a) and salt fog (b) without and after their passivating treatment $(10 \mathrm{~min})$ in aqueous solutions of IR $(16 \mathrm{mmol} / \mathrm{l})$ at $t=60^{\circ} \mathrm{C}$ and constant stirring, followed by drying the samples in air [40].

Thus, studies of the passivation of metals and their protection from atmospheric corrosion made it possible to identify and explain the relationship between the adsorption regularities of organic CIs, their chemical structure and passivating ability, as well as the effects of mutual enhancement of the protective effect of CIs in their mixtures.

\section{Vapor phase corrosion inhibition}

The protection of metals by volatile corrosion inhibitors (VCIs) is beyond the scope of temporary protection, although it is widely used, mainly in the form of packaging inhibited papers and polymer films, or on porous carriers, most often on silica gels (so-called linosils), which is convenient in case of liquid VCIs. The use of VCIs for the preservation of large-size equipment, including tanks in the oil industry, is widely known [3,8]. Such 
conservation can last for years, and if one takes into consideration that VCIs are used to protect the tank roof and its parts located above the air-hydrocarbon boundary, it becomes obvious that this type of vapor-phase protection is beyond "temporary". VCIs can be used not only against atmospheric corrosion, but also to protect the internal surface of pipelines in systems for collection and transportation of natural gas, including those containing corrosive gases such as $\mathrm{CO}_{2}$ or $\mathrm{H}_{2} \mathrm{~S}$ [45-47].

The term "VCIs" usually implies chemical compounds and their mixtures with sufficiently high vapor pressures (i.e. $p^{0} \geq 10^{-6} \mathrm{~mm} \mathrm{Hg}$ ) that easily evaporate at ordinary temperatures. Their vapors, reaching the metal surfaces, are adsorbed on them and form so thin protective films that they are invisible to the naked eye. Modern efficient VCIs can maintain protective nanoscale layers even after removing their carrier and then vapors from the packaging space. Such metal protection is explained by the irreversibility of adsorption of a VCI and its ability to form not only ultrathin chemisorption layers, but also next physically adsorbed layers whose desorption is hindered by structuring. Back in the past century, it was noticed for some heteroalkylated amines as an example that the protective aftereffect (PAE) can be maintained for 3 months even under conditions of $100 \%$ relative humidity with daily periodic condensation of moisture on low carbon steel and copper samples [48].

Over the past decade, the interest in making VCI adsorption more irreversible, and hence prolonging the PAE period, has increased markedly. Two methods for implementing this approach were suggested at the Frumkin Institute of Physical Chemistry and Electrochemistry of the Russian Academy of Sciences.

In one of them, formulations based on azomethines (IFKhAN 67) as VCIs were used. It was observed that its combinations with volatile additives apparently resulted in polymerization of their vapors on metal surfaces that gave the protective film some hydrophobicity, thus increasing its resistance to the action of condensing water [49]. Examples of such additives include volatile silanes, for example, (3-aminopropyl) triethoxysilane (Table 3) that can improve the protective properties of not only azomethines but also of one of the best domestic amine-based VCIs, IFKhAN 118.

Table 3. Protection of metals with VCI vapors, their salts and mixtures under conditions of $100 \%$ moisture and periodic condensation of moisture on the samples.

\begin{tabular}{cccccc}
\hline VCI & St3 & Cu & Zn & Alloy D16 & Brass \\
\hline IFKhAN-67 & ++ & + & + & ++ & + \\
\hline $\begin{array}{c}\text { IFKhAN-67 + (3-amino- } \\
\text { propyl) triethoxysilane }\end{array}$ & ++ & ++ & ++ & ++ & ++ \\
\hline IFKhAN-118 & ++ & ++ & \pm & + & ++ \\
\hline $\begin{array}{c}\text { IFKhAN-118+(3-amino- } \\
\text { propyl)triethoxysilane }\end{array}$ & ++ & ++ & + & ++ & Not tested \\
\hline
\end{tabular}


The other way involves the use of low volatile CIs that can be expected, in the case they form a protective film, to show slower desorption than the films formed by traditional VCIs. Earlier [49], attention was drawn to the fact that one of these CIs, namely octadecylamine $\mathrm{C}_{18} \mathrm{H}_{37} \mathrm{NH}_{2}$ (ODA), which is strongly adsorbed on steel surface at elevated temperatures and is widely used in heat and power engineering for the corrosion protection of steel equipment [51], shows very weak protective properties as VCI in an ordinary humid atmosphere [52]. Hence, for some compounds with relatively low saturated vapor pressure, increasing the temperature may facilitate and accelerate the formation of densely packed adsorption monolayers. Later, T. Ishizaki et al. [53] who studied the formation of self-assembled monolayers (SAMs) on a magnesium alloy from a vapor phase, found that on prolonged exposure of this alloy at $423 \mathrm{~K}$, SAMs that hydrophobize its surface can be formed. This is indicated by the contact angles of a water drop $\left(\theta_{\mathrm{c}}\right)$ on the modified surface, which reaches $100^{\circ}, 115^{\circ}$, and $125^{\circ}$, respectively, after a $70 \mathrm{~h}$ exposure with the best acids studied, i.e., stearic, octylphosphonic and 2-perfluoroethylphosphonic $\mathrm{CF}_{3}\left(\mathrm{CF}_{2}\right)_{5} \mathrm{CH}_{2} \mathrm{CH}_{2} \mathrm{PO}(\mathrm{OH})_{2}$ acids (PFEP). The protective properties of SAMs were estimated using EIS when the treated samples were immersed in $5 \% \mathrm{NaCl}$ solution, which confirmed that the best effect was observed in the case of treatment with PFEP. Of course, the prospects of such a long exposure in hot vapors of phosphonic acids raise many questions from the practical point of view. However, the authors apparently did not intend to assess the stability of the protective properties of the monolayers obtained, since they did not perform direct corrosion tests. At the same time, these studies are interesting because it was shown that not only ODA, but also organic acids can form protective monomolecular layers at elevated temperatures, that prevent the dissolution of an alloy of such a thermodynamically unstable metal as magnesium in a very corrosive neutral chloride solution.

However, systematic studies of the vapor-phase protection of metals at elevated temperatures began later. For this purpose, metal samples were suspended above a CI to be tested (ODA, BTA or their mixture) in glass cells, which were sealed and placed in a thermostat with a given temperature. After the exposure (usually $0.5-1.0 \mathrm{~h}$ ), samples of copper, steel [54,55] and zinc [56,57] were removed and tested for the PAE by electrochemical, accelerated and environmental corrosion methods. Important advantages of the chamber vapor-phase protection of metals are that the requirements for permeability of barrier packaging are mitigated and the range of non-toxic and available reagents for vapor-phase protection of metals is expanded. With this in mind, a new CI, IFKhAN-121, was developed at the Frumkin Institute of Physical Chemistry and Electrochemistry, RAS and the peculiarities of chamber zinc passivation by the CI were studied [56]. At present, chamber treatment of zinc with IFKhAN-121 demonstrates the best results as shown in Figure 6. After this treatment, the first signs of zinc corrosion appear not earlier than after 9 months, and it was shown that IFHAN-121 is well combined with other CIs that showed good protective properties on copper and steel. 


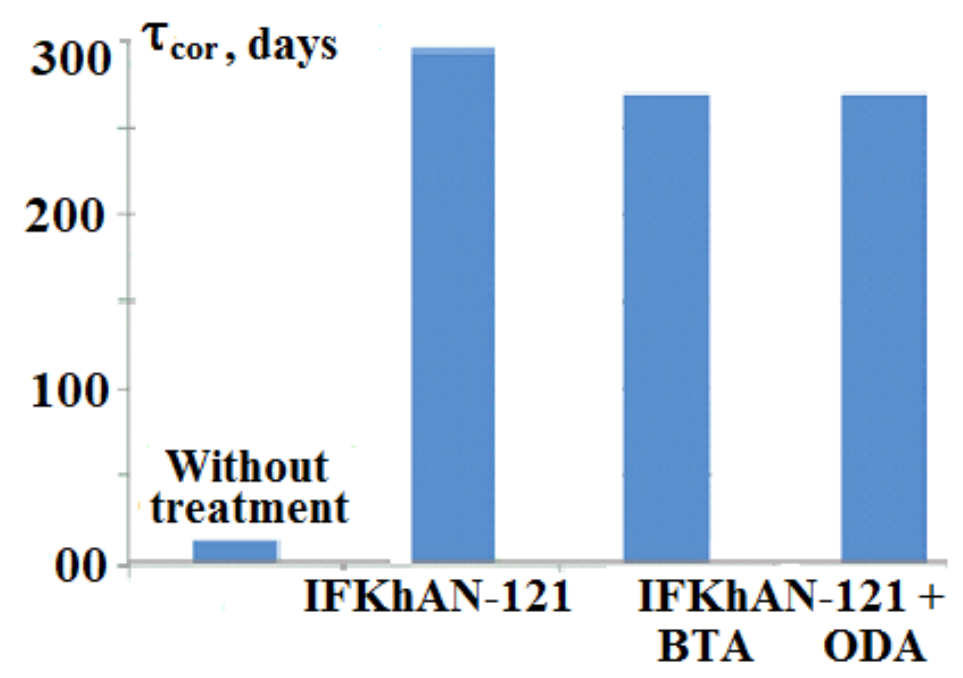

Figure 6. The results of field tests under a canopy at the Moscow Corrosion Station of the Frumkin Institute of Physical Chemistry and Electrochemistry, RAS, of zinc, previously processed in pairs of low volatile inhibitors and without it. Processing time -1 hour, $t=100^{\circ} \mathrm{C}$.

An increase in the protective effect of the chamber treatment of zinc in vapors of such CIs was also noticed if samples after the treatment were exposed in air at room temperature for $\sim 5$ hours. It is assumed that during this time, self-organization of the protective layer occurs, including CI chemisorption. It can be expected that the suggested method of vaporphase protection of metals will find its application in the protection not only from atmospheric corrosion, but also in other environments.

\section{Superhydrophobization of metal surfaces as an efficient method corrosion inhibition}

The hydrophobization of metal surfaces has long been a well-known method for preventing metal corrosion, but over the past decade interest in forming even more promising coatings on metals with the superhydrophobicity (SHPh) property increased considerably [58]. The SHPh phenomenon, known as the "lotus effect", is widespread in nature on plant surfaces [59]. The preparation of SHPh coatings is important for practical use, since it allows one not only to create coatings with high anti-corrosion properties but also to produce films that prevent biofouling, fogging or icing. Of great interest are SHPh sol-gel coatings, the production of which does not require high temperature or high pressure. They can be easily applied on various substrates. For example, such a coating on a copper plate made of superhydrophobic $\mathrm{SiO}_{2}$ retained $\mathrm{SHPh}$ even after 100 hours of immersion in $\mathrm{HCl}$ solution. The coating was still hydrophobic after exposure to air for 90 days.

$\theta_{\mathrm{c}}$ is the main parameter characterizing the hydrophobicity of a surface. Numerous experimental data on the determination of $\theta_{\mathrm{c}}$ obtained on smooth surfaces have shown that by varying the chemical composition of the surface layer, one can increase hydrophobicity only to a limited extent. Typical values of $\theta_{c}$ on smooth surfaces are $100-110^{\circ}$. When self- 
assembled monolayers SAM are applied, $\theta_{\mathrm{c}}$ can reach $115-116^{\circ}$, for example, in the case of dodecanethiols, and $118-120^{\circ}$ for monolayers with terminal $\mathrm{CF}_{3}$ groups [60].

The roughness of a wetted surface causes the deviation of the measured contact angle from $\theta_{c}$ on a smooth surface. On rough surfaces, one of two types of wetting occurs: homogeneous, in which the liquid completely fills the microscopic cavities, and heterogeneous, in which air is trapped inside the cavities. Thus, to achieve the SHPh condition, i.e. $\theta_{\mathrm{c}} \geq 150^{\circ}$, it is necessary to take the morphology of the surface microstructures into account.

Another important parameter of a SHPh coating is the roll-off angle of a drop from the surface. If the roll-off angle is high, the drop is fixed on the surface, thereby hindering the surface self-cleaning leading to a decrease in the corrosion resistance of the coating.

As a rule, the preparation of SHPh surfaces involves two stages: the formation of a surface with microstructural roughness, and then its modification by adsorption of compounds with low surface energy containing long alkyl and often perfluorinated chains [61]. To create the necessary roughness, it is possible to perform hydrothermal treatment of the product or anodizing, but this requires special conditions, expensive materials and complex technology, which so far limits the widespread use of SHPh coatings. In addition, many of the existing methods are based on the use of bio-toxic reagents - fluorinated silanes, which are still quite expensive. Alternatives to the use of F-containing compounds include higher organic acids [62], for example, phosphonic acids [63] or stearic acid (SA) [64].

In $[65,66]$, an affordable and environmentally safe method for obtaining SHPh coatings on the surface of aluminum alloys AD31 and AMg6 was suggested, involving the creation of a surface with polymodal roughness by alkaline etching and its subsequent modification with ethanol solutions of some trialkoxysilanes and SA. The results of $\Theta_{c}$ measurements in time with exposure of samples of AD31 with SHPh coatings in distilled water indicate a significant influence of the nature of the silane used on the stability of the GHPh coating (Figure 7). For samples modified in solutions of vinyltrimethoxysilane $\mathrm{H}_{2} \mathrm{C}=\mathrm{CH}-\mathrm{Si}\left(-\mathrm{OCH}_{3}\right)_{3}, \mathrm{VMS}$, and $\mathrm{SA}$ after 36 hours of exposure in water, $\theta_{\mathrm{c}}$ decreases to $148^{\circ}$. Only layer-by-layer treatment of AD31 alloy in octyltrimethoxysilane $\mathrm{H}_{3} \mathrm{C}\left(\mathrm{CH}_{2}\right)_{7} \mathrm{Si}$ ($\left.\mathrm{OCH}_{3}\right)_{3}$, OTS, and SA solutions after 36 hours of exposure to $\mathrm{H}_{2} \mathrm{O}$ retains its $\mathrm{SHPh}$ properties $\left(\theta_{\mathrm{c}}=152^{\circ}\right)$. At the same time, although a further exposure of the samples with the coatings obtained was accompanied by a decrease in $\theta_{c}$, but even after 49 days for all types of TAS and SA treatment, the coatings retained hydrophobicity.

The simplicity and cost-efficiency of this SHPh method can be used, for example, in protecting aluminum and its alloys from atmospheric corrosion. Tests under the most severe salt fog chamber (SFCh) conditions (Figure 8) showed that, despite the fact that the SHPh films lose stability in time, they have a sufficiently high protective ability. The layerby-layer superhydrophobization of the AD31 alloy in solutions of $10 \mathrm{mM}$ VMS and $10 \mathrm{mM}$ SA provides protection of the alloy for $\tau_{\text {cor }}=72 \mathrm{~h}$, and layer-by-layer 
superhydrophobization in solutions of $10 \mathrm{mM}$ OTS and $10 \mathrm{mM} \mathrm{SA}$ provides $\tau_{\text {cor }}=86 \mathrm{~h}$ and is the most efficient.

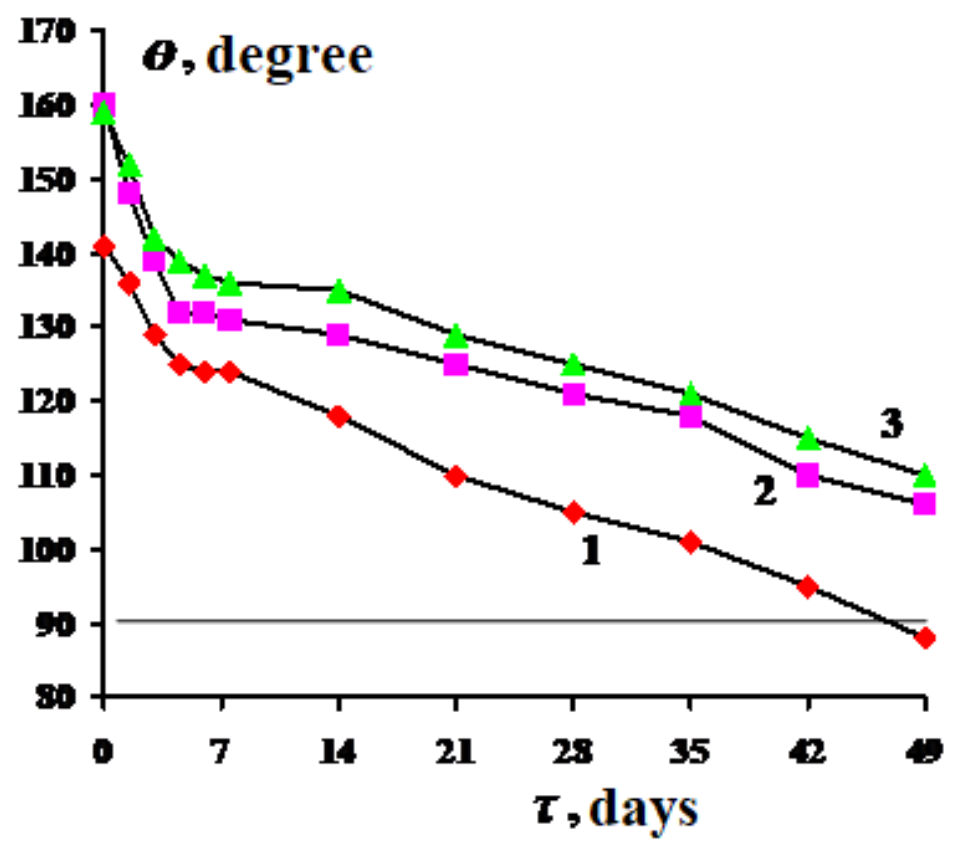

Figure 7. The change in the limiting angle $\Theta_{c}$ on samples of AD31 from the exposure time of them in distilled $\mathrm{H}_{2} \mathrm{O}$ treated in layers in ethanol solutions containing $(C$ in $\mathrm{mmol} / \mathrm{l}): 1-10$ SA; 2 - 10 VS and 10 OTS; 3 - 10 OTS and 10 SA.

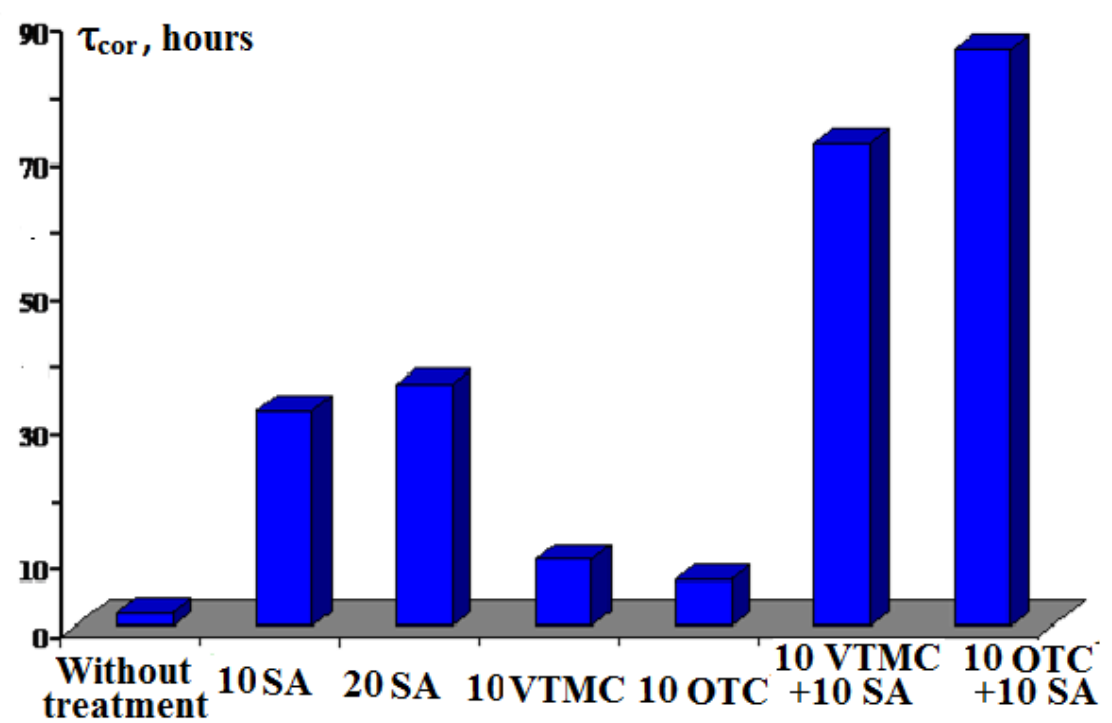

Figure 8. Time before the appearance of the first corrosion damage $\left(\tau_{\text {cor }}\right)$ on samples of alloy AD31 placed in a salt fog chamber without and with previously superhidrophobizating in ethanol solutions of CI with concentration $C(\mathrm{mmol} / \mathrm{l})$ indicated in the signature on the chart.

The development of stable SHPh coatings can be a promising technology for corrosion protection, also as an alternative to highly toxic $\mathrm{Cr}(\mathrm{VI})$ compounds in the 
passivation by their solutions. However, for a widespread use of SHPh materials it is necessary to increase the stability of SHPh layers, their chemical and antiwear resistance. This can be achieved by combining conversion coatings on metals with hydrophobic treatment using more efficient hydrophobic reagents are used, such as, for example, octadecylphosphonic acid $\mathrm{CH}_{3}\left(\mathrm{CH}_{2}\right)_{17} \mathrm{P}(\mathrm{O})(\mathrm{OH})_{2}$, ODPhA [19].

\section{Inhibition of steels corrosion in solutions of mineral acids and $\mathrm{H}_{2} \mathrm{~S}$-containing media}

As noted above, one of the important application areas of CIs in oil production is where injection of mineral acid solutions into the reservoir is performed to enhance oil recovery. Naturally, the use of strong acids, primarily $\mathrm{HCl}$, is impossible without the addition of efficient CIs to the solution because of the danger of corrosion destruction of pipes and well equipment by the acid. This is especially dangerous in deep wells, in which the temperature can exceed $120^{\circ} \mathrm{C}$, which sharply increases the corrosion rate of steels. As one can see from Figure 9, the corrosion rate of St20 in $2.0 \mathrm{M} \mathrm{HCl}$ at $120^{\circ}$ and $160^{\circ}$ exceeds 4 and $12 \mathrm{~kg} / \mathrm{m}^{2} \mathrm{~h}$, respectively. Such severe conditions make the corrosion protection of steels by the overwhelming majority of acid CIs inefficient.

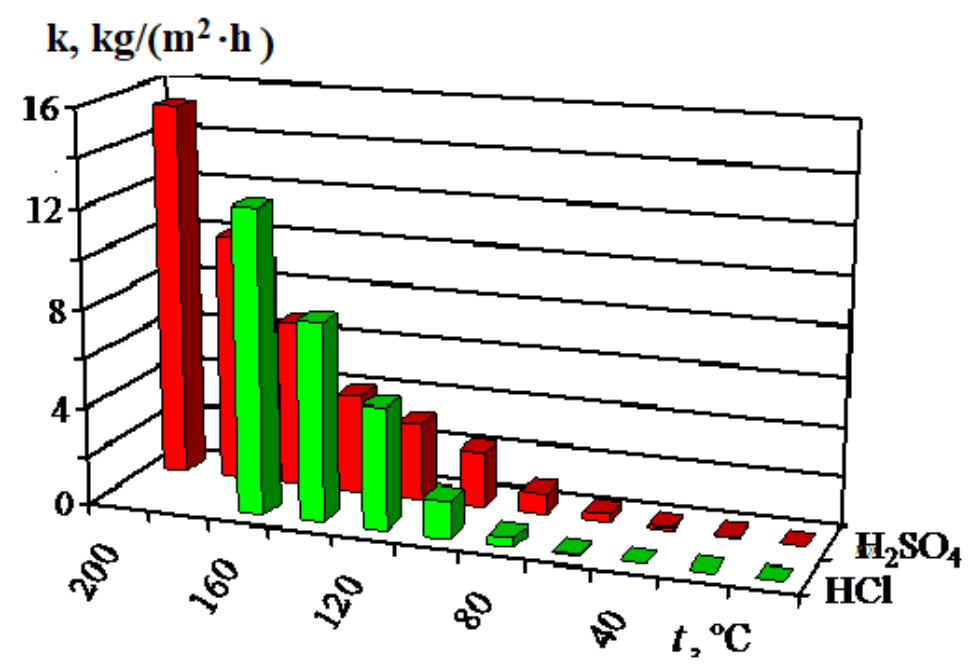

Figure 9. The corrosion rates of steel 20 in $2.0 \mathrm{M} \mathrm{HCl}$ and $\mathrm{H}_{2} \mathrm{SO}_{4}$, depending on temperature. The duration of the experiments is 0.5 hour.

In view of this, a CI comprosing a mixture of substituted 1,2,3-triazoles (IFKhAN-92) was developed and comprehensively studied at the Frumkin Institute of Physical Chemistry and Electrochemistry, RAS. It has good thermal stability and high protective properties in a wide range of temperatures (up to $200^{\circ} \mathrm{C}$ in solutions of $\mathrm{H}_{2} \mathrm{SO}_{4}$ and up to $160^{\circ} \mathrm{C}$ in $\mathrm{HCl}$ ). When this $\mathrm{CI}$ is added to $2.0 \mathrm{M} \mathrm{HCl}$, its maximum protective effect on mild steel St20 is observed at $80^{\circ} \mathrm{C}$ (Figure 10), but it remains high at $C_{\text {in }}=20 \mathrm{mmol} / 1$ even at higher temperatures. In fact, the corrosion rate of steel at $t=100^{\circ} \mathrm{C}$ and $120^{\circ} \mathrm{C}$ decreases 58.3- and 54.8-fold, respectively. Addition of urotropine (VD additive) does not have a high protective effect by itself but dramatically increases the coefficient of corrosion 
inhibition by IFKhAN-92, $\gamma=K_{\text {background }} / K_{\text {in }}$, bringing it to 163 even at $140^{\circ}$ (Figure 10). It is significant that in more concentrated solutions, for example, $6 \mathrm{M} \mathrm{HCl}$, this composition remains quite efficient for some time at high temperatures.

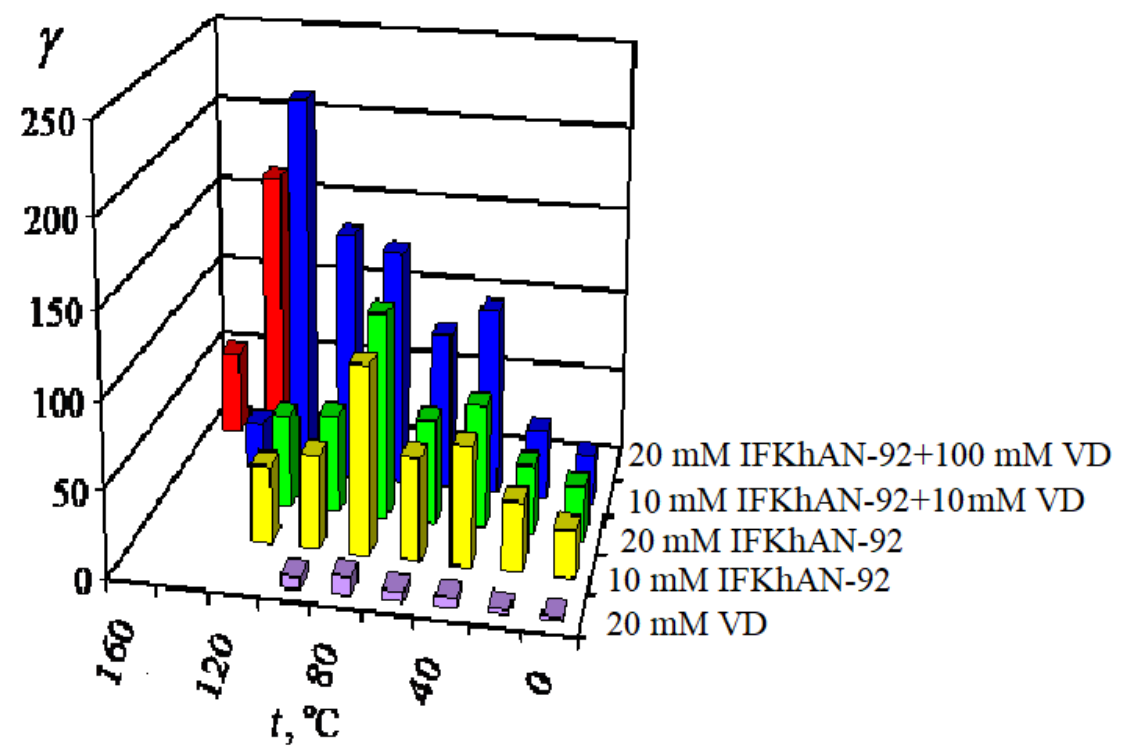

Figure 10. Inhibition coefficient of corrosion of steel 20 in $2.0 \mathrm{M} \mathrm{HCl}$ inhibitor IFKhAN-92, the addition of VD and their compositions. The duration of the experiments -0.5 hours.

It is interesting that the combined effect of IFKhAN-92 with urotropin has a positive effect when protecting steel $12 \mathrm{X} 18 \mathrm{H} 10 \mathrm{~T}$ from corrosion in $2.0 \mathrm{M} \mathrm{HCl}$ [70]. At the same time, a mixture of $1.0 \mathrm{mmol} / 1 \mathrm{IFKhAN}-92$ with $4 \mathrm{mmol} / 1$ urotropin at $t \leq 80^{\circ} \mathrm{C}$ increases $\gamma$ 1.4 to 1.6 fold in comparison with $5 \mathrm{mmol} / 1$ of IFHAN-92, although urotropin itself is nearly inefficient at the same $C_{\text {in }}$. This formulation begins to yield a little to IFKhAN-92 only at $100^{\circ} \mathrm{C}(\gamma=223$ and 234 , respectively), but its cost is significantly lower. It is proved that the suggested formulation provides a high level of protection for $12 \mathrm{X} 18 \mathrm{H} 10 \mathrm{~T}$ steel in a wide range of temperatures in hydrochloric acid solutions for at least 8 hours.

It has recently been shown that increasing the efficiency of $08 \mathrm{H} 18 \mathrm{~N} 10 \mathrm{~T}$ steel protection in $2.0 \mathrm{M} \mathrm{HCl}$ at high $t=80-160^{\circ}$ can be achieved by adding an equimolar amount of KI to the formulation of IFHAN-92 with hexamine (1:4). This reduces the corrosion rate of steel further, 5-10 fold [71].

IFKhAN-92 is also an efficient CI in $\mathrm{H}_{2} \mathrm{~S}$-containing media [72]. The results of corrosion tests of 08PS and 70C2XA steels sensitive to hydrogenation in the NACE environment $\left(0.5 \% \mathrm{NaCl}+0.25 \mathrm{~g} / 1 \mathrm{H}_{3} \mathrm{CCOOH}\right)$ in a wide range of $\mathrm{H}_{2} \mathrm{~S}$ concentrations show that IFHAN-92 exhibits a high protective effect against corrosion even at small $\mathrm{C}_{\text {in }} \leq 50 \mathrm{mg} / \mathrm{l}: Z=97-99 \%$ (Table 4). In addition, the amount of hydrogen absorbed by the steel, as determined by vacuum extraction remained at the metallurgical level, despite the presence of a strong hydrogen stimulant, such as $\mathrm{H}_{2} \mathrm{~S}$, maintaining the steel ductility at $80-100 \%$. 
As it shown in [73], the addition of $15 \mathrm{mM} \mathrm{H}_{2} \mathrm{~S}$ to $2 \mathrm{M} \mathrm{HCl}$ solution $\left(t=20 \div 100^{\circ} \mathrm{C}\right)$ significantly accelerates the corrosion of $1 \mathrm{X} 18 \mathrm{H} 9 \mathrm{~T}$ steel and significant steel hydrogenation occurs in this case. However, the mutual enhancement of the protective action of urotropine and IFKhAN-92 is undoubtedly preserved and their formulation becomes more efficient not only with increasing temperature, but also with the duration of exposure of steel samples in solution (Table 5).

Table 4. The effect of IFKhAN-92 on the corrosion rate $(k)$, degree of protection $(Z)$ and residual ductility $(p)$ of steels in a NACE solution containing $\mathrm{H}_{2} \mathrm{~S} . p_{\mathrm{N} 2}=1 \mathrm{~atm}$. 10 days, $t=25^{\circ} \mathrm{C}$.

\begin{tabular}{|c|c|c|c|c|c|c|}
\hline \multirow{3}{*}{$\mathrm{C}_{\mathrm{H}_{2} \mathrm{~S}}, \mathrm{~g} / \mathbf{l}$} & \multirow{3}{*}{$\begin{array}{c}\text { C }_{\text {IFKhAN-92, }} \\
\text { mg/l }\end{array}$} & \multicolumn{5}{|c|}{ Steel } \\
\hline & & \multicolumn{2}{|c|}{ O8PS } & \multicolumn{3}{|c|}{ 70S2KhA } \\
\hline & & $k, g /\left(\mathbf{m}^{2} \cdot \mathbf{h}\right)$ & $Z, \%$ & $k, g /\left(\mathbf{m}^{2} \cdot \mathbf{h}\right)$ & $Z, \%$ & $p, \%$ \\
\hline \multirow{3}{*}{0.1} & 0 & 0.090 & - & 0.140 & - & - \\
\hline & 25 & 0.020 & 77.8 & 0.009 & 93.5 & 45.0 \\
\hline & 50 & 0.018 & 80.0 & 0.016 & 88.5 & 86.0 \\
\hline \multirow{3}{*}{0.5} & 0 & 0.180 & - & 0.250 & - & - \\
\hline & 25 & 0.011 & 93.9 & 0.008 & 96.8 & 66.0 \\
\hline & 50 & 0.008 & 95.6 & 0.013 & 95.0 & 100.0 \\
\hline \multirow{3}{*}{2.0} & 0 & 0.230 & - & 0.430 & - & - \\
\hline & 25 & 0.005 & 97.8 & 0.005 & 98.8 & 30.0 \\
\hline & 50 & 0.003 & 98.7 & 0.006 & 98.6 & 80.0 \\
\hline
\end{tabular}

Table 5. Corrosion inhibition coefficients $(\gamma)$ of $1 \mathrm{X} 18 \mathrm{H} 9 \mathrm{~T}$ steel in $2 \mathrm{M} \mathrm{HCl}$ containing $15 \mathrm{mg} / \mathrm{l} \mathrm{H}_{2} \mathrm{~S}$ and $\mathrm{CI}$ at various $t$ and experiment durations $(\tau, \mathrm{h})$.

\begin{tabular}{cccccccc}
\hline & \multirow{2}{*}{ Corrosion inhibitor of steel } & \multicolumn{5}{c}{$\boldsymbol{\gamma}$ at temperature, ${ }^{\circ} \mathbf{C}$} \\
\cline { 3 - 7 } & & 20 & 40 & 60 & 80 & 100 \\
\hline \multirow{2}{*}{$5 \mathrm{mM}$ IFKhAN-92 } & 0.25 & 18 & 14 & 44 & 143 & 163 \\
& 0.5 & 16 & 16 & 67 & 145 & - \\
& 2.0 & 15 & 21 & 101 & - & - \\
\hline \multirow{2}{*}{$5 \mathrm{mM}$ urotropine } & 0.25 & 6.0 & 3.3 & 6.5 & 11 & 12 \\
& 0.5 & 6.8 & 4.1 & 12 & 17 & - \\
& 2.0 & 6.0 & 6.8 & 44 & - & - \\
\hline \multirow{2}{*}{$1 \mathrm{mM}$ IFKhAN-92+4 mM urotropine } & 0.25 & 24 & 27 & 48 & 143 & 250 \\
& 0.5 & 20 & 26 & 57 & 235 & - \\
& 2.0 & 18 & 21 & 122 & - & - \\
\hline
\end{tabular}




\section{Corrosion inhibitors in paint coating systems}

Stress corrosion cracking (SCC) rather than corrosion of steel itself is one of the most dangerous types of damage in gas pipelines [74]. Consideration of the causes of SCC is beyond the scope of this article, we only note that in most cases it is due to the presence of corrosion-fatigue cracks in the welded joint zone or subtle defects, i.e. stress concentrators (SC). Among the SCs on the outer surface of a pipe, there are dents, scratches and scores arising during the pipe transportation and gas pipeline construction. Despite the numerous measures taken to combat SCC, the issue of the danger of emergencies on high-pressure gas pipelines remains relevant. That is why a study conducted at the Frumkin Institute of Physical Chemistry and Electrochemistry of the Russian Academy of Sciences in collaboration with VNIIGAZ for the development of an efficient SCC inhibitor and for studying the mechanism of its protective action $[75,76]$ deserves attention.

At present, in order to combat external corrosion and SCC on high-pressure gas pipelines, the joint use of cathodic protection and anti-corrosion polymer coatings is prescribed. However, these measures are apparently insufficient to prevent the development of local corrosion processes, SCC in particular.

In laboratory studies, in addition to electrochemical studies on the effect of various CIs on the anodic dissolution of tubular steel electrodes of X70 strength class, the SSRT method (Slow Strain Rate Test) was used [75]. It involves slow $\left(10^{-8}-10^{-4} \mathrm{~mm} / \mathrm{s}\right.$ ) stretching of a smooth cylindrical specimen in a test medium until its rupture occurs. The time to rupture and the characteristics of the plasticity of the metal, viz., the relative elongation and contraction of the sample, are recorded during a test. The SSRT method is known as an accelerated method for comparative evaluation of the crack resistance of different steels, but it is very sensitive to changes in the electrode potential and the composition of the corrosive environment. The NS4 solution with $\mathrm{pH} 6.5-6.8$, the composition of which is close to that of the liquid under peeling coating of underground pipelines, is used as the test environment in the studies of SCC of pipe steels. The majority of researchers believe that the SCC of pipe steels in environments with near-neutral $\mathrm{pH}$ results from the synergistic effect of local anodic dissolution and hydrogen absorption by the steel [74]. In view of this, it is logical to use CIs, which suppress anodic dissolution and interfere with hydrogenation of steel, for the protection of pipelines from SCC.

Electrochemical studies have shown that addition of sodium sulfide $(10 \mathrm{mg} / 1)$ to NS4 solution increases the dissolution rate of tubular steel and prevents its passivation. However, addition of catamine AB (1 g/l) inhibits the active dissolution of steel, slows down the cathodic reaction rate and is an efficient inhibitor of steel hydrogenation. Testing of steel by the SSRT method (Figure 11) showed that catamin AB is an inhibitor of SCC and its protective action almost eliminates the negative effect of the environment, approaching the measured RA for a sample broken in air. Cathodic polarization of steel $(\mathrm{E}=0.6 \mathrm{~V})$ during the tests even facilitates protection, which is important for the practical application of inhibitor protection on a real gas pipeline. 


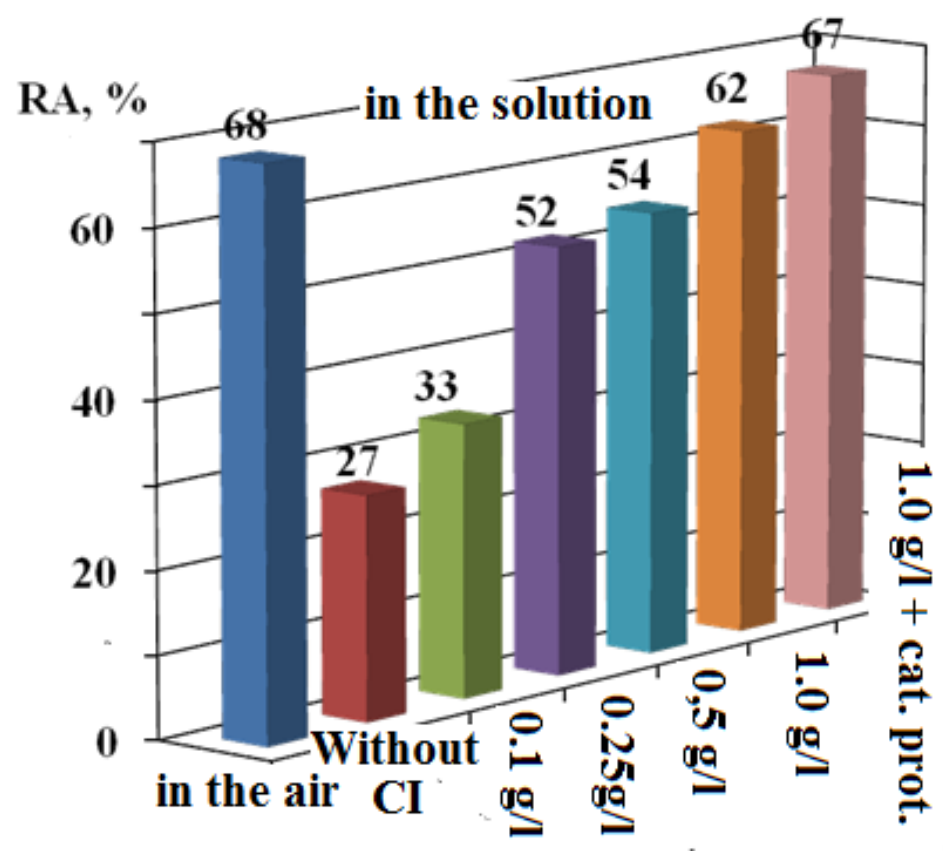

Figure 11. The magnitude of the relative narrowing of the steel (RA) sample after its rupture in an NS 4 solution containing $1 \mathrm{mmol} / 1 \mathrm{Na}_{2} \mathrm{~S}$ and katamine $\mathrm{AB}$ (in $\mathrm{g} / \mathrm{l}$ ) without and with cathodic polarization $(\mathrm{E}=-0.6 \mathrm{~V})$ of the sample.

Further studies led to the creation of composite inhibitors of SCC, which were introduced into the bitumen-polymer coating [76]. Comparative tests of adhesion strength, water resistance and resistance to cathodic peeling of adhesive joints, obtained with the technology of isolation of pipelines in the field and using new methods for pipe surface treatment, have been carried out. The results of complex laboratory studies and bench tests allowed us to recommend the two best inhibiting compositions: IFKhAN-29-ACh and IFKhAN-P-3.

It is necessary to briefly highlight another important possibility of using CIs in paint and varnish systems designed to protect metals and alloys from corrosion in corrosive environments. It is known that in this case, a large role is played by the layer adjacent to the metal, obtained by applying a primer formulation [77]. It usually contains pigments, fillers and a binder, and is convenient for the introduction of traditional CIs. However, as shown above, there are quite a few surfactants among the most efficient CIs. When such surfactants are adsorbed on the surface to be protected, they can impair the adhesion of paintwork materials to the metal. Some CIs can chemically interact with a binder and prevent the coating from curing, which is also undesirable for their introduction into the primer. Water-soluble CIs are often quickly washed out of a coating, which weakens its barrier properties and reduces the protection period. At the same time, water-containing primers should contain CIs that are capable of preventing metal corrosion during the formation of the primer layer and curing of the coating, and also not to prevent its adhesion during operation of the item [78]. Over the past decades, the method of using CIs in paint and varnish system has been actively developed. It consists of placing it in nano- or 
microcontainers, which prevents the negative effect of organic CIs on the functioning of the coating, while maintaining the increase in the efficiency of metal corrosion protection [78-81].

As an example, let us consider the possibility of producing silica particle containers with a high content of sodium $\mathrm{N}$-oleoylsarcosinate (SOS) loaded at the sol-gel stage of particle synthesis by using its micelles as a template [81]. It is known that the content of the templating functional compound in such containers reaches $1 \mathrm{~g}$ or more per $1 \mathrm{~g}$ of $\mathrm{SiO}_{2}$. In addition, they are highly sensitive to the $\mathrm{pH}$ of the medium, which makes it possible to regulate the rate of desorption (output) of template molecules in a wide range without any additional modification of the surface of the particles. Containers provide gradual dosing of SOS into a corrosive environment, which suggests that they can be successfully used with SOS immobilized in them as part of an organic coating. The results of polarization measurements also showed the output of SOS from containers in an amount sufficient for spontaneous passivation of steel. Earlier in our laboratory, high adsorption and inhibitory capacity of SOS with respect to $\mathrm{Fe}, \mathrm{Cu}, \mathrm{Zn}, \mathrm{D} 16$ aluminum alloy and other metals was shown. Table 6 shows the test results of $\mathrm{SOS}$ in water and $\mathrm{SiO}_{2}$ containers, from which it follows that the output of $\mathrm{CI}$ from the container is slow, but in combination with a small addition of free SOS it can maintain a high level of steel protection (Z). To obtain paintwork materials, a PF-0294 alkyd primer was used, which was applied with a brush in 1 layer. The layer thickness was determined using a thickness gauge based on magneticinductive and eddy current methods, with a resolution of $5 \mu \mathrm{m}$.

Table 6. Results of corrosion tests of St 3 in a solution with $\mathrm{pH} 7.4$ containing $30 \mathrm{mg} / \mathrm{l} \mathrm{NaCl}$ and $70 \mathrm{mg} / \mathrm{l}$ $\mathrm{Na}_{2} \mathrm{SO}_{4}$, in the presence of free $\mathrm{SOS}$ encapsulated in $\mathrm{SiO}_{2}$ containers.

Test duration

\begin{tabular}{|c|c|c|c|c|c|c|}
\hline \multirow{2}{*}{$\begin{array}{l}\text { Solution } \\
\text { composition }\end{array}$} & \multicolumn{2}{|c|}{7 days } & \multicolumn{2}{|c|}{14 days } & \multicolumn{2}{|c|}{32 days } \\
\hline & $\begin{array}{c}K, \\
\mathrm{~g} / \mathrm{m}^{2} \text { day }\end{array}$ & $Z, \%$ & $\begin{array}{c}K, \\
g / m^{2} \text { day }\end{array}$ & $Z, \%$ & $K, \mathrm{~g} / \mathrm{m}^{2}$ day & $Z, \%$ \\
\hline Without CI & 0.74 & - & 0.72 & - & 0.69 & - \\
\hline $0.5 \mathrm{~g} / 1 \mathrm{SOS}$ & 0.05 & 93.2 & 0.07 & 90.3 & 0.08 & 88.4 \\
\hline $0.5 \mathrm{~g} / 1 \mathrm{SiO}_{2}-\mathrm{SOS}$ & 0.65 & 12.2 & 0.60 & 16.7 & 0.53 & 23.2 \\
\hline $1.0 \mathrm{~g} / 1 \mathrm{SiO}_{2}-\mathrm{SOS}$ & 0.60 & 18.9 & 0.55 & 23.6 & 0.45 & 34.8 \\
\hline $\begin{array}{c}0.5 \mathrm{~g} / 1 \mathrm{SOS}+0.5 \mathrm{~g} / 1 \\
\mathrm{SiO}_{2}-\mathrm{SOS}\end{array}$ & - & - & 0.05 & 93.0 & 0.05 & 92.7 \\
\hline
\end{tabular}

The protective properties of the coatings were compared with a content of $0 ; 2$ and $4 \%$ of containers with immobilized SOS. At up to $4 \%$ containers with SOS in the primer formulation, no changes in the curing rate of the coating were observed, and the level of its 
adhesion with respect to St3 steel determined by the cross-cut method (GOST 31149-2014) was 1 point in all cases. At the same time, incorporation of pure SOS into the primer, even at its content as small as 1\%, markedly hampered the coating curing.

The protective ability of the paintwork was determined by testing samples of St3 and alloy D16 in an SFCh. On one side of each sample coated by the alkyd primer, a crossshaped incision was made to the metal surface. The results of corrosion tests of St3 steel samples coated by the alkyd primer showed that on steel samples with the coating, signs of corrosion along the coating notches appeared in 1-2 days. After 240 hours of testing, the coatings exfoliated in the notch area and corrosion products accumulated on control samples with the initial paintwork material. After 500 hours, corrosion lesions appeared on the control samples at a short distance from the incisions, which indicates the development of subfilm corrosion. On samples with paintworks containing $2 \%$ of containers with SOS, there were significantly fewer signs of corrosion, while at $4 \%$ they were practically not observed. This indicates that the efficiency of encapsulated SOS increases with an increase in $C_{\text {in }}$. After termination of the tests and removal of the paintwork from the control samples, the zone of corrosion development was in some cases greater than $15 \mathrm{~mm}$ from the incision. On samples protected by paintwork containing $4 \%$ of containers with SOS, corrosion after removal was detected only along the notch lines (in the form of individual spots, the size of which did not exceed 3-4 mm).

Significantly higher corrosion resistance in comparison with steel is observed for samples of D16 alloy coated with the same primer. After 500 hours of testing, no signs of corrosion products or detachment of paintwork were detected on their surface, even along the notch lines. After 1500 hours, a small amount of corrosion products was observed only on the control samples (Figure 12). After removal of the paintwork, corrosion damage was practically absent on samples protected by the primer with $4 \%$ capsules containing SOS. Minor changes along the notch lines were found on samples with $2 \%$ encapsulated SOS, although the alloy corrosion on these samples was significantly weaker than on the control samples.

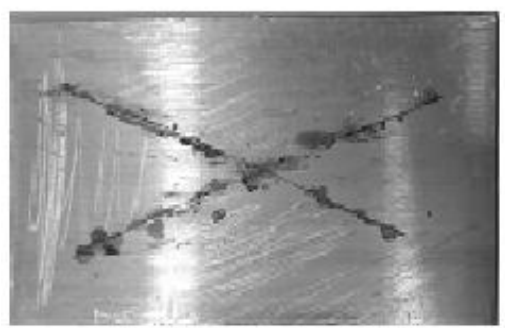

a

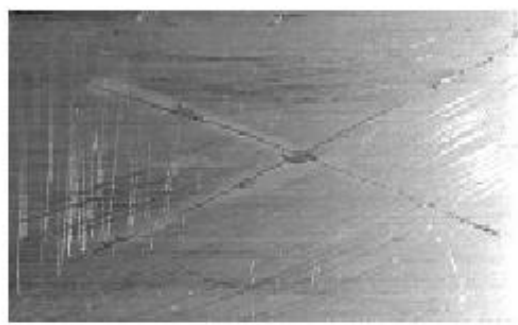

b

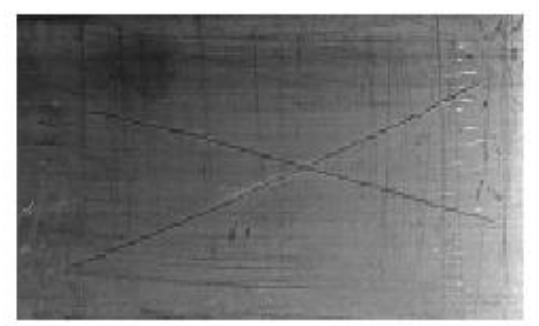

c

Figure 12. Photographs of samples after corrosion testing of $\mathrm{SiO}_{2}-\mathrm{SOS}$ containers in the composition of the PF-0294 primer and removal of paintwork: (a) a control sample, (b) $2 \%$ of $\mathrm{SiO}_{2}$-SOS particles, (c) $4 \%$ of $\mathrm{SiO}_{2}$-SOS particles. Coating thickness 60-65 microns; substrate - aluminum alloy D16. The test time in the salt fog chamber is $1500 \mathrm{~h}$. 


\section{Conclusion}

The scope of CIs for the protection of metals and methods of their application in the oil and gas industry is constantly being improved. At the same time, the requirements for environmental and fire safety of CI application are becoming tougher, therefore, some of the traditional CIs (chromates, nitrites, salts of heavy metals, etc.) should be replaced, in spite of their quite acceptable protective properties. This question is acute in the protection from atmospheric corrosion. Over the past decade, studies have been conducted on the mechanism of metal passivation with aqueous solutions and in the vapor-gas phase, which has allowed the development of non-toxic and efficient CIs that can provide temporary and long-term protection against corrosion of metals (alloys).

In the methods of temporary protection, one can distinguish the successive two-stage passivation that allows one to increase the efficiency of ultrathin passivating layers and to use combinations of CIs that are poorly compatible or totally incompatible in aqueous solutions, as well as to decrease the $C_{\text {in }}$ in passivating solutions significantly.

In the case of vapor-phase protection, much attention is paid to increasing the irreversibility of VCI adsorption and, as a result, the duration of the PAE. At the Frumkin Institute of Physical Chemistry and Electrochemistry of the RAS, two ways of its implementation were suggested. In one of them, a VCI is used in conjunction with volatile additives, for example silanes, whose vapors are capable of entering condensation or polymerization reactions on metal surfaces. This, at least, reduces the possibility of desorption, not only of these additives but also of the VCI, and also gives some hydrophobicity to the protective film. In the other method, it is recommended to use CIs with low volatility, which are placed in a chamber together with the metal product to be protected. A high temperature is maintained in the chamber, which increases the CI volatility and chemisorption, which dramatically increases the PAE. It was suggested to call this as chamber passivation and the CIs used, as chamber CIs.

A relatively new and rapidly developing method for metals protection is the SHPh of their surfaces. It involves the creation of a surface with polymodal roughness and its subsequent treatment with solutions of higher carboxylic or phosphonic acids and other hydrophobic CIs.

Pumping solutions of strong acids, such as $\mathrm{HCl}$, into the reservoir (to increase oil production) is impossible without adding efficient CIs because of the danger of destruction of pipes and well equipment by the acid. This is especially importain in for deep wells where the temperature can exceed $120^{\circ} \mathrm{C}$. A developed $\mathrm{CI}$ based on mixtures of substituted 1,2,3-triazole (IFHAN-92) has good heat resistance and high protective properties (for $\mathrm{HCl}$ at $\mathrm{t} \leq 160^{\circ} \mathrm{C}$ ). It is possible to increase the efficiency of this CI by synergistic additives, such as urotropin. IFKhAN-92 is an efficient CI not only for various steels in acid solutions, but also in $\mathrm{H}_{2} \mathrm{~S}$-containing media. It suppresses metal hydrogenation and retains a high level of protection of steels in acid solutions upon accumulation of $\mathrm{Fe}$ (III) cations, which is a problem for most CIs. 
Increasing the protective effect of paintworks is another important area of application of CIs where the layer adjacent to the metal plays a significant role. It is applied with a primer that contains pigments, fillers and a binder. It is also convenient to introduce CIs into it; however, many of the most efficient CIs are surfactants, which adsorb on the surface to be protected and can impair the adhesion of paintwork materials, chemically interact with the binder and hinder the curing of coating. Over the past decade, the method of CI addition to paint systems in the form of nano- and micro-containers was actively developing. This prevents the negative effect of CIs on the operation of a coating, while maintaining an increase in the efficiency of protection from metal corrosion.

As an example, silica particles-containers with a high content of SOS, an anionic CI of many metals, which was loaded at the stage of sol-gel synthesis of the particles using its micelles as a template, were obtained. A significant increase in the protection efficiency of the coating on St3 steel and D16 alloy upon incorporation of these containers into PF-0294 alkyd primer was shown.

A serious problem in the prevention of the destruction of gas pipelines lies not in the corrosion of steel itself but in its stress corrosion cracking (SCC). It appears that the use of cathodic protection and an anticorrosive polymer coating is not efficient enough to solve this problem. As a result of studies of the mechanism of CI action along with laboratory and bench tests, SCC inhibitors IFKhAN-29ACH and IFKhAN-P-3 that possess a combination of properties required for addition to bitumen-polymer coatings used to protect pipelines have been developed and recommended for industrial testing.

\section{References}

1. Standard ISO 8044-1989.

2. Khimicheskaya Encyclopedia (Chemical Encyclopedia), Vol. 2., Ed.: I.L. Knunyants, Soviet Encyclopedia, Moscow, 1990, 434-436 (in Russian).

3. A.A. Mikhailov, Yu.M. Panchenko and Yu.I. Kuznetsov, Atmosphernaya korroziya I zashchita metallov (Atmospheric corrosion and protection of metals), Pershin Publishing House, Tambov, 2016, 555 pp. (in Russian).

4. A.J. Szyprowski, Corrosion Inhibition in Refinery Processes, In "A Working Party Report on Corrosion Inhibitors", Eur. Fed. Corros. Publ., The Institute of Materials, London, 1994, no. 11, 121-144.

5. J. Gitzeit and J.M. Johnson, Corrosion Inhibitors for Petroleum Refinery and Petrochemical operations, In the book: Reviews on Corrosion Inhibitor Science and Technology, Eds.: A. Raman and P. Labine, Houston, TX: NACE, 1993, II-4-1 - II-416.

6. J.I. Bregman, Corrosion Inhibition, Macmillan, New York, 1963, 320 pp.

7. V.N. Glushchenko and M.A. Silin, Neftepromyslovaya khimiya. Vol. 4. Kislotnaya obrabotka skvazhyn (Oilfield chemistry. Vol. 4. Matrix acidizing), Ed.: I.T. Mishchenko, Intercontact Nauka, Moscow, 2010, 703 pp. (in Russian). 
8. V.V. Burlov, A.I. Altsibeeva and T.M. Kuzinova, Sistema zashchity ot korrozii oborudovaniya pererabotki nefti (Corrosion protection system of oil refining equipment), Publishing House "Profession", St. Petersburg, 2015, 336 pp. (in Russian).

9. V.P. Tomin and Ya.N. Silinskaya, Corrosion in Processes of Deep Destructive CrudeOil-Processes, Prot. Met. Phys. Chem. Surf., 2010, 46, no. 7, 758-762.

10. V.V. Burlov, A.I. Altsibeeva and I.V. Parputz, Zashchita ot korrozii oborudovaniya NPZ (Corrosion protection of refinery equipment), Khimizdat, St. Petersburg, 2005, 248 pp. (in Russian).

11. Yu.I. Kuznetsov, Organic Inhibitors of Corrosion of Metals, Plenum Press, New York and London, 1996, 283 pp.

12. D.F. Meier and J.T. Montgomery, Performance results of the long-term application of a novel corrosion inhibitor and active polymer dosage control in industrial cooling water systems, In Proc. of the $10^{\text {th }}$ European Symp. on Corrosion and Scale Inhibitors, University of Ferrara, 2005, 325-343.

13. A.A. Chirkunov and Yu.I. Kuznetsov, Corrosion inhibitors in cooling water systems, Chapter 4 in the book: Mineral Scales and Deposits: Scientific and Technological Approaches, Eds.: Z. Amjad and K.D. Demadis, Elsevier B.V., 2015, 85-105.

14. A.A. Chirkunov, Yu.I. Kuznetsov and A.S. Gorbachev, O modifikatsii passiviruyushchykh sostavov IFKhAN-39 dlya zashchity stali ot atmosfernoi korrozii (On the modification of passivating composition IFHAN-39 to protect steel from atmospheric corrosion), Korroz.: mater., zashch. (Corrosion: materials, protection), 2010, no. 5, 30-34 (in Russian).

15. Yu.A.Zhdanov and V.I. Minkin, Korrelyatsionny Analis v Organicheskoy Khimii (Correlation Analysis in Organic Chemistry), RGU Publishing House, Rostov-on-Don, 1966, 470 pp. (in Russian).

16. B.B. Damaskin, O.A. Petry and V.V. Batrakov, Adsorbtsiya Organicheskykh Soyedinenii na Elektrodakh (Adsorption of organic compounds on the electrodes), Nauka, Moscow, 1968, p. 205, 300, 75 (in Russian).

17. Yu.I. Kuznetsov and N.P. Andreeva, On Joint Adsorption of Mefenamic and Phenylundecanoic Anions on Passive Iron, Prot. Met., 2005, 41, no. 4, 1-5.

18. Yu.I. Kuznetsov and N.P. Andreeva, Ellipsometric study of the adsorption of organic anions on iron from aqueous solutions, Russ. J. Electrochem., 2006, 42, no. 10, 12241229.

19. Yu.I. Kuznetsov, N.P. Andreeva, N.P. Sokolova, R.A. Bulgakova and A.M. Gorbunov, On the design of the structure of adsorption films of mefenamic and phenylundecanoic acids on passive iron, Prot. met., 2007, 43, no. 4, 339-345.

20. L. Bellamy, Infrakrasniye spektry slozhnykh molekul (Infrared spectra of complex molecules), Inostrannaya literatura, Moscow, 1963, 462 pp. (in Russian).

21. Yu.I. Kuznetsov, N.P. Andreeva and M.O. Agafonkina, On Co-Adsorption on Passive Iron from Aqueous Solutions of 1,2,3-Benzotriazole and Sodium Phenylundeconate, Russ. J. Electrochem., 2010, 46, no. 5, 560-564. 
22. Yu.I. Kuznetsov, A.A. Chirkunov and I.A. Philippov, On the effect of the surface modification of steel with oxyethylidene diphosphonate of zinc on its passivation with solutions of some inhibitors, Russ. J. Electrochem., 2013, 49, no. 12, 1235-1245.

23. A.A. Chirkunov, I.A. Philippov and Yu.I. Kuznetsov, Vliyaniye hydroxyethylidene diphosphonat a medi na passivatsiyu nizkouglerodistoy stali organicheskimi ingibitorami (Effect of copper hydroxyethylidene diphosphonate on the passivation of low carbon steel by organic inhibitors), Korroz.: mater., zashch. (Corrosion: materials, protection), 2013, no. 7, 29-34 (in Russian).

24. A.A. Chirkunov, I.A. Philippov, D.O. Chugunov, G.V. Redkina and Yu.I. Kuznetsov, The Influence of Steel Surface Modifying with Zinc Complexes of Phosphonic Acids on the Efficiency of Its Passivation by Organic Inhibitors, Russ. J. Electrochem., 2019, 55, no. 2, 115-121.

25. M.R. Tarasevich, K.A. Radyushkina and V.A. Bogdanovskaya, Elektrokhimiya porfirinov (Porphyrin Electrochemistry), Nauka, Moscow, 1991, 310 pp. (in Russian).

26. M.S. Dyer, A. Robin, S. Haq, R. Raval, M. Persson and J. Klime, Understanding the interaction of the porphyrin macrocycle to reactive metal substrates: structure, bonding andadatom capture, ACS Nano, 2011, 5, no. 3, 1831-1838.

27. Yu.I. Kuznetsov, M.O. Agafonkina, N.P. Andreeva and A.B. Solov'eva, Modification of Iron Surface by Dimegin and Adsorption of 1,2,3-benzotriazole, Prot. Met. Phys. Chem. Surf., 2010, 46, no. 7. 743-747.

28. Yu.I. Kuznetsov, M.O. Agafonkina, N.P. Andreeva and L.P. Kazansky, Adsorption of dimegin and inhibition of copper dissolution in aqueous solutions, Corros. Sci., 2014, 100, 535-543. doi: $10.1016 /$ j.corsci.2015.08.028

29. M.A. Petrunin, A.P. Nazarov and Yu.N. Mikhailovskii, Electrochemical and corrosion behavior of steel, magnesium, and aluminum primed with silanes, Prot. Met., 1990, 26, 749-754.

30. E.P. Pluddemann, Silane Coupling Agents, 2nd edition, Springer US, New York, 1991, $253 \mathrm{pp}$.

31. A.P. Nazarov and M. Stratman, Adsorption of Methoxysilane on an Iron Surface and Corrosive Behavior of Formed Surface in a Corrosive Environment, Prot. Met., 1994, 30, no. 1, 52-58.

32. G.L. Witucki, A Silane Primer: Chemistry and Applications of Alkoxy Silanes, J. Coat. Technol., 1993, 65, no. 822, 57.

33. J.M. Chen, F.D. Osterholtz, E.R. Pohl, P.E. Ramdatt, A. Chaves and V. Bennett, Silanes in High-Solids and Waterborne Coatings, J. Coat. Technol., 1997, 69, no. 870, 43-51. doi: 10.1007/BF02696251

34. V.V. Menshikov, A.A. Kalinkina, D.V. Mazurova, E.F. Akimova and T.A. Vagramian, Primeneniye vodnykh rastvorov silanov dlya podgotovki poverkhnosti metalla pered naneseniyem lakokrasochnykh pokrytii (The use of aqueous solutions of silanes to prepare the metal surface before applying paint coatings (review)), Korroz.: mater., zashch. (Corrosion: materials, protection), 2010, no. 4, 30-37 (in Russian). 
35. A.M. Beccaria and L. Chiaruttini, The inhibitive action of metacryloxypropylmethoxysilane (MAOS) on aluminium corrosion in $\mathrm{NaCl}$ solutions, Corros. Sci., 1999, 41, 885-899. doi: 10.1016/S0010-938X(98)00161-9

36. A. Frignani, F. Zucchi, G. Trabanelli and V. Grassi, Protective action towards aluminium corrosion by silanes with a long aliphatic chain, Corros. Sci., 2006, 48, no. 8, 2258-2273. doi: $10.1016 /$ i.corsci.2005.06.018

37. A.A. Chirkunov, A.M. Semiletov, Yu.I. Kuznetsov and N.P. Andreeva, Passivation of Steel with Aqueous Solutions of Trialkoxysilanes, Prot. Met. Phys. Chem. Surf., 2015, 51, no. 7, 1154-1159. doi: 10.1134/S2070205115070059

38. M.A. Petrunin, L.B. Maksayeva, T.A. Yurasova, E.V. Terekhova, V.A. Kotenev and A.Yu. Tsivadze, Adsorption of alkoxysilanes on the surface of aluminum from aqueous solutions, Prot. Met. Phys. Chem. Surf., 2013, 49, no. 6, 655-661. doi: 10.1134/S2070205113060117

39. A.M. Semiletov, A.A. Chirkunov, Yu.I. Kuznetsov and N.P. Andreeva, Improving steel passivation with aqueous solutions of [3-(2Aminoethylamino)propyl]trimethoxysilane, Russ. J. Phys. Chem. A, 2015, 89, no. 12, 2271-2277.

40. A.A. Chirkunov, Yu.I. Kuznetsov and A.A. Chirkunov, Ingibirovaniye atmosphernoy korrozii aluminiyevogo splava AMg6 trialkoksysilanami i kompozitsiyami s karboksylatami (Inhibition of atmospheric corrosion of aluminum alloy AMg6 by trialkoxysilanes and their compositions with carboxylates), Korroz.: mater., zashch. (Corrosion: materials, protection), 2016, no. 6, 29-36.

41. Yu.I. Kuznetsov, A.M. Semiletov, A.A. Chirkunov, I.A. Arkhipushkin, L.P. Kazansky and N.P. Andreeva, Protecting Aluminum from Atmospheric Corrosion via Surface Hydrophobization with Stearic Acid and Trialkoxysilanes, Russ. J. Phys. Chem. A, 2018, 92, no. 4, 621-629.

42. N. Gladkikh, Yu. Makarychev, M. Maleeva, M. Petrunin, L. Maxaeva, A. Rybkina, A. Marshakov and Yu. Kuznetsov, Syntesis of thin organic layers containing silane coupling agents and azole on the surface of mild steel. Synergizm of inhibitors for corrosion protection of underground pipelines, Prog. Org. Coat., 2019, 132, 481-489. doi: 10.1016/j.porgcoat.2019.04.004

43. A.M. Semiletov, A.A. Chirkunov and Yu.I. Kuznetsov, Protection of alloy AD31 from corrosion by adsorption layers of trimethoxysilanes and stearic acid, Mater. Corros., 2019. doi: $10.1002 /$ maco.201911000

44. M.A. Petrunin, N.A. Gladkikh, M.A. Maleeva, L.B. Maksayeva and T.A. Yurasova, Primeneniye organosilanov dlya ingibirovaniya korrozii metallov (The use of organosilanes to inhibit the corrosion of metals, Review), Korroz.: mater., zashch. (Corrosion: materials, protection), 2019, no. 10, 1-10 (in Russian).

45. N.N. Andreev and Yu.I. Kuznetsov, Volatile inhibitors of $\mathrm{CO}_{2}$-corrosion, CORROSION-98, NACE, Houston, San Diego, 1998, Paper no. 241. 
46. R.K. Vagapov, Osnovaniya Schiffa kak letuchiye ingibitory serovodorodnoy korrozii stali (Schiff bases as volatile inhibitors of hydrogen sulfide corrosion of steel), Dissertatsiya kandidata khimicheskikh nauk ( $\mathrm{PhD}$ Chemistry Dissertation), A.N. Frumkin Institute of Physical Chemistry, Russian Academy of Sciences, Moscow, 2001 (In Russian).

47. R.V. Kashkovskii, Ingibirovaniye serovodorodnoy korrozii nizkouglerodistoy stali letuchimi aminami (Inhibition of hydrogen sulfide corrosion of low carbon steel with volatile amines), Dissertatsiya kandidata khimicheskikh nauk (PhD Chemistry Dissertation), A.N. Frumkin Institute of Physical Chemistry, Russian Academy of Sciences, Moscow, 2011 (In Russian).

48. Yu.I. Kuznetsov, The Role of Irreversible Adsorption in the Protective Action of Volatile Corrosion Inhibitors, CORROSION-98, NACE, Houston, San Diego, 1998, Paper no. 242.

49. Yu.I. Kuznetsov, N.N. Andreev, O.A. Goncharova and A.V. Agafonkin, O zashchite metallov ot korrozii pri kondensatsii na nikh vlagi letuchimi ingibitorami (On the protection of metals from corrosion at moisture condensation on them by volatile inhibitors), Korroz.: mater., zashch. (Corrosion: materials, protection), 2009, no. 10, 29-33 (In Russian).

50. A.V. Agafonkin, Yu.I. Kuznetsov and N.P. Andreeva, Formation of Protective NanoLayers on Metals Formed by Benzylbenzyliden-imine and (3-Aminopropyl)triethoxysilane from Gas-Vapor Phase, Prot. Met. Phys. Chem. Surf., 2011, 47, no. 7, 866-872. doi: 10.1134/S2070205111070021

51. A.P. Akolzin, Protivokorrozionnaya zashchita stali plenkoobrazovatelyami (Anticorrosive protection of steel by filmformers), Metallurgia, Moscow, 1989, $192 \mathrm{pp}$. (In Russian).

52. I.L. Rozenfeld, V.P. Persiantseva, M.N. Polteva and P.B. Terent'ev, Investigation of the mechamism of protection of metals of volatile inhibitors, In Proc. of the 1st European Symposium on Corrosion Inhibitors, Ferrara (Italie), 1961, 329-356.

53. T. Ishizaki, M. Okido, Y. Masuda, N. Saito and M. Sakamoto, Corrosion Resistant Performances of Alkanoic and Phosphonic Acids Derived Self-Assembled Monolayers on Magnesium Alloy AZ31 by Vapor-Phase Method, Langmuir, 2011, 27, 6009-6017. doi: $10.1021 / 1 \mathrm{a} 200122 \mathrm{x}$

54. A.Yu. Luchkin, O.A. Goncharova, N.N. Andreev, Yu.I. Kuznetsov and N.P. Andreeva, Zashchita medi obrabotkoy parami maloletuchikh ingibitorov pri povyshennykh temperaturakh (Copper protection by treating the vapors of low-volatile inhibitors at elevated temperatures), Korroz.: mater., zashch. (Corrosion: materials, protection), 2017, no. 11, 25-31 (In Russian). 
55. A.Yu. Luchkin, O.A. Goncharova, N.N. Andreev and Yu.I. Kuznetsov, Zashchita stali obrabotkoy parami oktadetsylamina, 1,2,3-benzotriazola i ikh smesi pri povyshennykh temperaturakh (Protection of steel by treating the vapors of octadecylamine and 1,2,3benzotriazole vapors and their mixture at elevated temperature), Korroz.: mater., zashch. (Corrosion: materials, protection), 2017, no. 11. 25-31 (In Russian).

56. O.A. Goncharova, Yu.I. Kuznetsov, N.N. Andreev, A.Yu. Luchkin, N.P. Andreeva and D.S. Kuznetsov, A new corrosion inhibitor for zinc chamber treatment, Int. J. Corros. Scale Inhib., 2018, 7, no. 3, 340-351. doi: 10.17675/2305-6894-2018-7-3-5

57. L.B. Boinovich and A.M. Emelianenko, Hydrophobic materials and coatings: principles of design, properties and applications, Russ. Chem. Rev., 2008, 77, no. 7, 583-600. doi: 10.1070/RC2008v077n07ABEH003775

58. W. Bartlott and C. Neinhuis, Purity of the sacred lotus, or escape from contamination in biological surfaces, Planta, 1997, 202, no. 1, 1-8. doi: $10.1007 / \mathrm{s} 004250050096$

59. T. Nishino, M. Meguri, K. Nakamae, M. Matsushita and Y. Ueda, The lowest surface free energy based on $-\mathrm{CF}_{3}$ alignment, Langmuir, 1999, 15, no. 13, 4321-4323. doi: 10.1021/la981727s

60. Ph.M. Barkhudarov, P.B. Shah, E.B. Watkins, D.A. Doshi, C.J. Brinker and J. Majewski, Corrosion inhibition using superhydrophobic films, Corros. Sci., 2008, 50, 897-902. doi: 10.1016/j.corsci.2007.10.005

61. L. Zhao, Q. Liu, R. Gao, J. Wang, W. Yang and L. Liu, One-step method for the fabrication of superhydrophobic surface on magnesium alloy and its corrosion protection, antifouling performance, Corros. Sci., 2014, 80, 177-183. doi: 10.1016/j.corsci.2013.11.026

62. Y. Huang, D.K. Sarkar and X.G. Chen, Superhydrophobic aluminum alloy surfaces prepared by chemical etching process and their corrosion resistance properties, Appl. Surf. Sci., 2015, 356, 1012-1024. doi: 10.1016/j.apsusc.2015.08.166

63. E. Hoque, J.A. DeRose, P. Hoffmann, H.J. Mathieu, B. Bhushan and M. Cichomski, Phosphonate self-assembled monolayers on aluminium surfaces, J. Chem. Phys., 2006, 124, 174710. doi: $10.1063 / 1.2186311$

64. A.M. Semiletov, Yu.I. Kuznetsov and A.A. Chirkunov, O gidrofobizatsii poverkhnosti splava AMg6 i ego zashchite ot atmosfernoy korrozii kompozitsiyami vys'shikh karboksilatov i triakoksysilanov (On the hydrophobization of the surface of the AMg6 alloy and its protection from atmospheric corrosion with mixtures of higher carboxylates with trialkoxysilanes), Korroz.: mater., zashch. (Corrosion: materials, protection), 2017, no. 6, 24-30 (In Russian).

65. A.M. Semiletov, A.A. Chirkunov and Yu.I. Kuznetsov, Protection of aluminum alloy AD31 from corrosion by adsorption layers of trialkoxysilanes and stearic acid, Mater. Corros., 2019, 1-9. doi: 10.1002/maco.201911000 
66. Ya.G. Avdeev and A.Yu. Luchkin, Effect of IFKhAN-92 inhibitor on electrode reactions and corrosion of mild steel in hydrochloric and sulphuric acid solutions, Int. J. Corros. Scale Inhib., 2013, 2, no. 1, 53-66. doi: 10.17675/2305-6894-2013-2-1-053$\underline{066}$

67. L.I. Antropov, E.M. Makushin and V.A. Panasenko, Ingibitory korrozii metallov (Inhibitors of corrosion of metals), Tekhnika, Kiev, 1981, 172 pp. (In Russian).

68. Ya.G. Avdeev, L.V. Frolova, Yu.I. Kuznetsov and O.O. Zel, Vliyanie proizvodnykh triazola na korroziyu hromonikelevykh staley $\mathrm{v}$ rastvorakh mineral'nykh kislot (The effect of triazole derivatives on the corrosion of nickel-chrome steels in solutions of mineral acids), Korroz.: mater., zashch. (Corrosion: materials, protection), 2010, no. 8, 19-24 (In Russian).

69. Ya.G. Avdeev, D.S. Kuznetsov and Yu.I. Kuznetsov, Zashchita khromonikelevoy stali v rastvorakh mineral'nykh kislot zameshchennym triazolom, Ch. 1. Solyanaya kislota (Protection of Steels by Inhibitors in Solutions of Mineral Acids by Substituted Triazole. P. 1. Hydrochloric acid), Korroz.: mater., zashch. (Corrosion: materials, protection), 2014, no. 11, 15-22 (In Russian).

70. Ya.G. Avdeev, D.S. Kuznetsov and S.V. Oleinik, Ingibitornaya zashchita staley v rastvorakh solyanoyj kisloty $\mathrm{v}$ usloviyakh vysokotemperaturnoy korrozii (do $160^{\circ} \mathrm{C}$ ) (Inhibitor protection of steels in hydrochloric acid solutions under conditions of high temperature corrosion (up to $\left.160^{\circ} \mathrm{C}\right)$ ), Korroz.: mater., zashch. (Corrosion: materials, protection), 2017, no. 1, 39-47 (In Russian).

71. Yu.I. Kuznetsov, Ya.G. Avdeev and L.V. Frolova, Ingibitornaya zashchita metallov v kislykh sredakh (Protection of Metals by Inhibitors in Acidic Environments), Khimicheskaya tekhnika (Chemical engineering), 2013, no. 9, 19-21 (In Russian).

72. Ya.G. Avdeev, L.V. Frolova and D.S. Kuznetsov, Ingibitornaya zashchita khromonikelevoy stali v rastvorakh solyanoy kisloty soderzhashchikh serovodorod (Inhibitory protection of chromium-nickel steel in hydrochloric acid solution containing hydrogen sulfide), Korroz.: mater., zashch. (Corrosion: materials, protection), 2016, no. 3, 4147 (In Russian).

73. A.I. Malkin, A.I. Marshakov, V.E. Ignatenko and A.B. Arabey, Protsessy zarozhdeniya i rosta korrozionnykh treshchin na stali magistral'nykh truboprovodov (Processes of birth and growth of corrosion cracks on steel of main pipelines), Korroz.: mater., zashch. (Corrosion: materials, protection), 2009, no. 10, 1-15; 2010, no. 2, 1-13 (In Russian).

74. V.E. Ignatenko, Yu.I. Kuznetsov, A.B. Arabey, R.V. Igoshin, R.I. Bogdanov and A.I. Marshakov, Primenenie metoda SSRT dlya otsenki vliyaniya sostava korrozionnoy sredy na sklonnost' trubnoy stali X70 k rastreskivaniyu pod napryazheniem (Application of the SSRT method to assess the influence of the composition of the corrosive environment on the tendency of X70 pipe steel to crack under stress), Korroz.: mater., zashch. (Corrosion: materials, protection), 2011, no. 9, 16-25 (In Russian). 
75. M.A. Maleeva, M.A. Petrunin, A.I. Marshakov, V.E. Ignatenko, A.V. Shapagin, G.V. Redkina, Yu.I. Kuznetsov, L.B. Maksayeva, T.A. Yurasova, R.I. Bogdanov and I.S. Ryakhovsky, Razrabotka ingibirovannykh polimernykh kompozitsiy s tsel'yu predotvrashcheniya riska KRN na magistral'nykh gazoprovodakh (Development of inhibited polymer compositions in order to prevent the risk of SCC on gas pipelines), Korroziya territorii NEFTEGAZ (Corrosion of the territory NEFTEGAZ), 2015, no. 2, 24-32 (In Russian).

76. A.S. Drinberg, E.F. Itzko and T.V. Kalinskaya, Antikorrozionnye gruntovki (Anticorrosion primer), LLC "Paint Media", Moscow, 2008, 168 pp. (In Russian).

77. V.A. Golovin, Kompozitnye polimernye zashchitnye pokrytiya dlya agressivnykh sred (Composite polymer protective coatings for aggressive environments), Korroz.: mater., zashch. (Corrosion: materials, protection), 2011, no. 2, 1-11 (In Russian).

78. M.L. Zheludkevich, D.G. Shchukin, K.A. Yasakau, H. Möhwald and M.G.S. Ferreira, Anticorrosion Coatings with Self-Healing Effect Based on Nanocontainers Impregnated with Corrosion Inhibitor, Chem. Mater., 2007, 19, 402-411. doi: $10.1021 / \mathrm{cm} 062066 \mathrm{k}$

79. M.L. Zheludkevich, J. Tedim and M.G.S. Ferreira, "Smart" coatings for active corrosion protection based on multi-functional micro and nanocontainers, Electrochim. Acta, 2012, 82, 314-323. doi: 10.1016/j.electacta.2012.04.095

80. T. Szabó, J. Telegdi and L. Nyikos, Linseed oil-filled microcapsules containing drier and corrosion inhibitor - Their effects on self-healing capability of paints, Progr. Org. Coat., 2015, 84, 136-142. doi: 10.1016/j.porgcoat.2015.02.020

81. O.V. Dementieva, A.M. Semiletov, A.A.Chirkunov, V.M. Rudoy and Yu.I. Kuznetsov, Sol-Gel Synthesis of $\mathrm{SiO}_{2}$ Con-tainers Using Micelles of an Anionic Corrosion Inhibitor as a Template and the Prospects of Creation of Protective Coatings Based on them, Colloid J., 2018, 80, no. 5, 478-483. doi: $\underline{10.1134 / \mathrm{S} 1061933 \mathrm{X} 18050058}$ 